\title{
The Psychology of Conflicts of Interest in Criminal Cases
}

\author{
Tigran W. Eldred ${ }^{*}$
}

\section{INTRODUCTION}

Criminal cases are fraught with the risk of conflicting interests. ${ }^{1}$ For example, a conflict can arise when one attorney represents two or more defendants in the same proceeding, or when defense counsel previously represented either the victim or a prosecution witness. ${ }^{2}$ In such situations, are defense attorneys well-suited to determine whether a conflict exists or is likely? Or are there reasons to doubt whether attorneys can assess the risks of divided loyalties, both prospectively when deciding the likelihood of a conflict, and retrospectively when testifying about whether they provided constitutionally effective representation? ${ }^{3}$

\footnotetext{
* Visiting Assistant Clinical Professor, Hofstra University School of Law. Copyright Tigran W. Eldred 2009. This article was written when I taught as a Clinical Law Professor at Lewis \& Clark Law School. Special thanks to Bruce Green, Juliet Stumpf, Bridget McCormack, Michael Pinard, Megan Chaney, Barb Fedders, Jenny Roberts, Susan Mandiberg and Jennifer Stumpf for their helpful comments on earlier drafts of this paper. Thanks also to Lewis \& Clark Law School for funding support; to the organizers of New York University School of Law's Clinical Writer's Workshop, where I presented an earlier version of this paper; and to my research assistants, Lauren Kemp and Lais Washington.

1. Conflicts of interest are frequently litigated in criminal cases. For example, Cuyler v. Sullivan, 446 U.S. 335 (1980), a seminal decision on conflicts in criminal cases, has been cited 1137 times in the last five years (based on May 22, 2009 Westlaw search limited to state and federal cases, run with date restriction of February 22, 2004). Limiting the search to Westlaw Headnotes nineteen and twenty-one (which focus on the applicable standard of review to determine whether a conflict of interest resulted in ineffective assistance of counsel, see infra notes 72-77 and accompanying text), there have been 693 case citations during the same period. For a discussion of the ratio of alleged to actual conflicts of interest, see infra text of note 192.

2. For discussion of the most common scenarios that present risks of a conflict, see infra notes $28-55$ and accompanying text.

3. Commentary on the right to effective assistance of counsel, as guaranteed by the Sixth Amendment, is voluminous. For a sampling of recent scholarship, see Rebecca Klaren \& Irene Merker Rosenberg, Splitting Hairs in Ineffective Assistance of Counsel Cases: An Essay on How Ineffective Assistance of Counsel Doctrine Undermines the Prohibition Against Executing the Mentally Retarded, 31 AM. J. CRIM. L. 339 (2004); Eve Brensike Primus, Structural Reform in Criminal Defense: Relocating Ineffective Assistance of Counsel Claims, 92 CORNELl L. REV. 679 (2007); Robert R. Rigg, The T-Rex Without Teeth: Evolving Strickland v. Washington and the Test for Ineffective Assistance of Counsel, 35 PEPP. L. REV. 77 (2007).
} 
Mickens v. Taylor, ${ }^{4}$ the Supreme Court's most recent decision on conflicts of interest in criminal cases, places these questions in context. The defendant, Walter Mickens, was charged with the murder and attempted forced sodomy of seventeen-year-old Timothy Hall. ${ }^{5}$ Unbeknownst to Mickens, his appointed attorney, Bryan Saunders, had been representing the victim on unrelated criminal charges at the time of the murder. ${ }^{6}$ Saunders did not disclose his prior representation of the victim, which only became known years later, well after Mickens had been convicted and sentenced to death for the crime.

Mickens filed a petition for habeas corpus in federal court alleging that Saunders had a conflict of interest that justified a new trial. ${ }^{7}$ Of the many claims, one stands out: the allegation that Saunders had failed, due to his prior representation of the victim, to investigate whether the victim had been a male prostitute who consented to sexual relations with Mickens before the murder. ${ }^{8}$ The importance of a consent defense was

4. 535 U.S. 162 (2002). Mickens has received extensive scrutiny. See, e.g., Lawrence J. Fox, Making the Last Chance Meaningful: Predecessor Counsel's Ethical Duty to the Capital Defendant, 31 Hofstra L. ReV. 1181 (2003); John Capone, Note, Facilitating Fairness: The Judge's Role in the Sixth Amendment Right to Effective Counsel, 93 J. CRIM. L. \& CRIMINOLOGY 881 (2003); Jeffrey Scott Glassman, Note, Mickens v. Taylor: The Court's New Don't Ask, Don't Tell Policy for Attorneys Faced with a Conflict of Interest, 18 St. John's J. Legal Comment. 919 (2004); Hadassah Reimer, Case Note, Legal Ethics: Stabbed in the Back, But No Adverse Effect, Mickens v. Taylor, 122 S. Ct. 1237 (2002), 3 Wyo. L. REV. 329 (2003); Patrice McGuire Sabach, Note, Rethinking Unwaivable Conflicts of Interest After United States v. Schwartz and Mickens v. Taylor, 59 N.Y.U. AnN. Surv. AM. L. 89 (2003); Mark W. Shiner, Note, Conflicts of Interest Challenges Post Mickens v. Taylor: Redressing the Defendant's Burden in Concurrent, Successive, and Personal Interest Conflicts, 60 WASH. \& LEE L. REV. 965 (2003).

5. Mickens, 535 U.S. at 164. Post-conviction counsel admitted that the evidence that Mickens had committed the murder was "strong." See Brief for Petitioner at *3, Mickens v. Taylor, 535 U.S. 162 (2002) No. 00-9285, 2001 WL 930725 [hereinafter Brief for Petitioner]. The facts of the case, as found by the Virginia Supreme Court and adopted by the federal courts in deciding the habeas petition, were as follows: The victim was found lying nude from the waist down on a mattress under a sheet of plywood and had been stabbed 143 times. Id. at $* 2$. After his arrest, Mickens made incriminating statements on multiple occasions; the victim's shoes were found in the possession of someone who had bought them from Mickens; and forensic evidence found at the scene, including semen, blood, and saliva on cigarette butts, were tested for DNA, which either matched or did not exclude Mickens. See Mickens v. Greene, 74 F. Supp. 2d 586, 589-93 (E.D. Va. 1999), aff'd en banc, 240 F.3d 348 (4th Cir. 2001), aff'd sub nom. Mickens v. Taylor, 535 U.S. 162 (2002).

6. See Greene, 74 F. Supp. 2d at 599-600.

7. Id. at 592. The petition alleged a number of constitutional violations, including that Saunders's conflict of interest had caused him to: (1) refrain from investigating and asserting a consent defense to the charge of attempted sodomy, which would have eliminated the statutory basis for the death penalty; (2) fail to investigate or raise negative information about Hall; (3) fail to engage in meaningful plea negotiations; and (4) fail to present evidence about Hall as mitigating information at the sentencing proceeding. $I d$. at 606 .

8. Id. at 606-08. During the habeas proceedings, Mickens cited the following evidentiary support for a consent defense, claiming it was sufficient to warrant an investigation into whether the victim had been a male prostitute: a newspaper clipping indicating that the area where the body had been found was known as a place where "male homosexuals frequent"; no defensive stab wounds on 
evident: to impose the death penalty, the jury was required by statute to find that the murder had occurred during the commission of attempted forced sodomy, meaning that a finding of consent would have eliminated the possibility of a death sentence. ${ }^{9}$ Mickens argued that Saunders failed to investigate a consent defense out of loyalty to the victim. ${ }^{10}$

Saunders testified during the habeas proceedings that, in his opinion, his ethical duties to the victim had ended at the victim's death, that he had obtained no confidential information from the victim, and that his prior representation of the victim had not influenced his decisions on behalf of Mickens. ${ }^{11}$ On the issue of consent, Saunders testified that he did not consider the defense because Mickens had maintained his innocence and had never suggested that the sexual activity was consensual. $^{12}$

The habeas court concluded that Saunders had been "remarkably wrong" in calculating his ethical duties. ${ }^{13}$ Nevertheless, it "accord[ed] great weight" to Saunders's claim that his prior representation of the victim had not "hampered" his work on behalf of Mickens. ${ }^{14}$ On the issue of consent, the court agreed with Saunders that Mickens's persistent claim of innocence had foreclosed a consent defense. ${ }^{15}$ Based

the victim's body; forensic evidence from the mattress on which the victim's body had been found indicated the presence of pubic hair from several different people, suggesting that it had been frequently used for sexual relations; the area where the crime had been committed was known for prostitution; and the victim had been killed at the base of an embankment, where it would have been difficult to lead someone involuntarily. Id. at 606-07.

9. See VA. Code ANN. § 18.2-31(5) (West 2001).

10. Brief for Petitioner, supra note 5, at 39-41. According to Mickens's post-conviction counsel, Saunders obtained information from the victim that would have prompted a non-conflicted attorney to start an investigation, including that, at the time of the murder, the victim had been living away from home, had been in state custody, and had been assigned a state social worker. Id. at 3944. Mickens's post-conviction lawyers also claimed that Saunders knew, but did not disclose, why the victim had been placed in state custody. $I d$. at 39 .

11. Greene, 74 F. Supp. $2 \mathrm{~d}$ at 605.

12. Id. at 608 .

13. Id. at 605 (noting that Saunders's duty to protect Hall's confidences continued past death) (citing Swidler \& Berlin v. United States, 524 U.S. 399 (1998)). The court also found that it was "inconceivable" that Saunders had obtained no confidential information from the victim. Greene, 74 F. Supp. 2d at 606.

14. Greene, 74 F. Supp. $2 \mathrm{~d}$ at 605.

15. Id. at 606-07. Remarkably, the district court did not analyze the obvious counter-argument to this position: namely, that Mickens's insistence on his own innocence might have been thawed by advice of a non-conflicted lawyer who had investigated the defense and, based on the results, had explained to Mickens that a consent defense would have the best chance of staving off a sentence of death. See Mickens v. Taylor, 535 U.S. 162, 179-83 (2002) (Stevens, J., dissenting) (noting that Saunders's decision to conceal his prior representation of the victim, and the truncated investigation that followed, made it impossible for Saunders to develop the type of trusting relationship that would have prompted truthful disclosures by Mickens about his responsibility for Hall's death). In addition, the habeas court noted that other evidence undermined the claim of consensual sex, 
on these findings, and after addressing the remaining claims of error, the court denied relief. ${ }^{16}$ The Supreme Court affirmed. ${ }^{17}$

Mickens raises two important questions about defense lawyers in conflicts cases. First, can lawyers such as Saunders be depended upon to make accurate judgments about whether a conflict exists or is likely? On this question, the Supreme Court, which has been the main authority on the matter, has made inconsistent statements in different cases. When formulating rules for conflicts that are alleged before or during representation, the Court has expressed distrust in the competence of defense lawyers to guarantee effective assistance of counsel. As a result, the Court has vested trial courts with broad discretion to disqualify counsel to protect against conflicts that can arise. ${ }^{18}$

The Court's views have been very different, however, when defining standards for post-conviction claims of ineffective assistance of counsel. Under the current standard, a defendant who seeks to overturn a conviction on conflicts grounds must prove, in most cases, that a conflict had an adverse effect on the quality of representation provided. ${ }^{19}$ In developing this test, the Court has expressed confidence in the abilities of defense lawyers, noting that trial courts must "necessarily rely in large measure upon the good faith and good judgment of defense counsel" and that defense attorneys are in the "best position" to evaluate whether a conflict exists or is likely. ${ }^{20}$

including evidence of a choke hold on the victim's neck and evidence of bloody transfer stains suggesting that the perpetrator stabbed the victim during attempted sexual activity. See Greene, 74 F. Supp. $2 \mathrm{~d}$ at 607 . Because Saunders did not investigate the possibility of a consent defense, there is no way to know whether this evidence would have withstood careful investigation and examination. In this regard, the court's analysis is an example of the inherent problems of after-thefact review in ineffectiveness cases identified by Justice Marshall in Strickland v. Washington, the seminal decision regarding the Sixth Amendment right to effective assistance of counsel. See 466 U.S. 668, 710 (Marshall, J., dissenting) (explaining that assessing prejudice based on the record developed at trial is an inherently suspect act of bootstrapping, since the record under review was produced by the very attorney whose conduct is alleged to have been ineffective). For a detailed discussion and elaboration of this critique, see Donald A. Dripps, Ineffective Assistance of Counsel: The Case for an Ex Ante Parity Standard, 88 J. CRIM. L. \& CRIMINOLOGY 242, 278-86 (1997).

16. Greene, 74 F. Supp. $2 \mathrm{~d}$ at 615.

17. Mickens, 535 U.S. at 176. The Supreme Court's decision in Mickens was based, in large measure, on its interpretation of precedent. See infra note 80 and accompanying text.

18. See Wheat v. United States, 486 U.S. 153, 164 (1988). For discussion of Wheat, see infra notes 58-65 and accompanying text.

19. See Cuyler v. Sullivan, 446 U.S. 335, 348-50 (1980). A limited exception to the Sullivan adverse effects test applies when defense counsel objected to representing conflicting interests, but the trial court failed to inquire into whether a conflict was present. Id. at 348 . In such situations, reversal is automatic without any showing of prejudice. See Holloway v. Arkansas, 435 U.S. 475, 485-90 (1978). See infra notes 67-71 and accompanying text.

20. See Sullivan, 446 U.S. at 345-47; Holloway, 435 U.S. at 485-86. 
A second question arises when defense attorneys such as Saunders testify in post-conviction proceedings: can lawyers be expected to make accurate retrospective assessments about whether they rendered effective assistance of counsel? On this point, some have suggested that defense lawyers will succumb to psychological biases when testifying. For example, the United States Court of Appeals for the Second Circuit has stated:

[A]fter-the-fact testimony by a lawyer who was precluded by a conflict of interest from pursuing a strategy or tactic is not helpful. Even the most candid persons may be able to convince themselves that they actually would not have used that strategy or tactic anyway, when the alternative is a confession of ineffective assistance resulting from ethical limitations. $^{21}$

Which of these many claims about defense lawyers is accurate? Too often, the tendency has been to make "generalizations about the ethical probity of defense lawyers," 22 and then to draw conclusions about how they will respond when confronted with difficult questions such as conflicts of interest. ${ }^{23}$ Indeed, despite the many assertions about defense lawyers, no attempt has been made to assess empirical evidence on how they actually respond to conflicts of interest in criminal cases.

21. United States v. Malpiedi, 62 F.3d 465, 470 (2d Cir. 1995). See also United States v. Shwayder, 312 F.3d 1109, 1118-19 (9th Cir. 2002) ("Human self-perception regarding one's own motives for particular actions in difficult circumstances is too faulty to be relied upon, even if the individual reporting is telling the truth as he perceives it."). A group of legal ethics experts made a similar suggestion in Mickens, arguing as amicus curiae that Saunders suffered "subconscious" divided loyalties caused by conflicting interests. See Brief of Legal Ethicists and the Stein Center for Law and Ethics as Amici Curiae in support of Petitioner at*15, Mickens v. Taylor, 535 U.S. 162 (2002) No. 00-9285, 2001 WL 881242 [hereinafter Brief of Legal Ethicists].

22. Bruce A. Green, "Through A Glass Darkly": How the Court Sees Motions to Disqualify Criminal Defense Lawyers, 89 CoLUM. L. REV. 1201, 1228 (1989).

23. One major exception is Leonard Gross from Southern Illinois University, who has studied empirical evidence on how lawyers behave when conflicts of interest are present. See Leonard E. Gross, Are Differences Among the Attorney Conflict of Interest Rules Consistent with Principles of Behavioral Economics?, 19 GEO. J. LEGAL ETHICs 111 (2006). Gross addresses whether the ethical duties that bind lawyers should be modified to reflect the psychological biases that can distort judgment caused by conflicts of interest. Id . at 125 . His conclusion is that lawyers are subject to distorting biases of judgment that make it hard to respond objectively to conflicts of interest. $I d$. at 125-33. While Gross covers similar terrain as the research cited in this article, his work does not focus on the particular types of conflicts that arise in criminal cases, nor the relevance of psychological data on legal standards that should apply in cases of ineffective assistance of counsel under the Sixth Amendment. His work is very useful, however, in assessing the degree to which the rules of professional responsibility act as a check to psychological biases confronting lawyers in conflicts cases. See infra notes $147-49$ and accompanying text. 
This Article fills the gap in existing scholarship by applying psychological research from the field of behavioral economics ${ }^{24}$ to the types of decisions that lawyers make to resolve conflicts of interest in criminal cases. The evidence, it turns out, is quite revealing. Researchers have uncovered psychological biases that make it extremely difficult for professionals, even those who are acting in good faith and whose only limitation is unconscious, to appreciate the deleterious consequences of conflicts of interest. ${ }^{25}$ In other words, while the "venal" evidence of a conflict of interest, or the harmful effects that a conflict had during representation, psychological research demonstrates that most lawyers - even those who are acting with the best intentions - are unable consciously to identify many conflicts that exist or to appreciate the corrosive effects that such conflicts may have on decision making. Indeed, like all professionals, lawyers systematically understate both the existence of conflicts and their deleterious effects.

This Article is divided into three parts. Part II reviews the types of conflicts of interest that can arise in criminal cases and analyzes the Supreme Court's current jurisprudence, with an emphasis on assumptions about whether defense lawyers are well-suited to resolve conflicts of interest. It also reviews the importance of defense attorney testimony in resolving allegations of ineffective assistance of counsel. Part III explores the psychological biases that cause lawyers

24. Behavioral economics has been defined as the field that "attempts to incorporate the vast knowledge accumulated by cognitive and social scientists into predictive models" of human behavior. On Amir \& Orly Lobel, Stumble, Predict, Nudge: How Behavioral Economics Informs Law and Policy, 108 COLuM. L. REV. 2098, 2098-99 (2008) (reviewing Richard H. THALER \& Cass R. Sunstein, Nudge: Improving Decisions About Health, Wealth And Happiness (2008) and Dan Ariely, Predictably Irrational: The Hidden Forces That Shape Our DECISIONS (2008)). As a noted scholar has stated, "[T] here is little doubt that the major new theoretical approach to law and economics in the past two decades does not come from either of these two fields. Instead it comes from the adjacent discipline of cognitive psychology, which has now morphed into behavioral economics." Richard A. Epstein, The Neoclassical Economics of Consumer Contracts, 92 MINN. L. REV. 803, 803 (2008). For a description of the research trends in this area, including the application of behavioral economics to various areas of legal study, see infra notes 101-02 and accompanying text.

25. See, e.g., Dolly Chugh et al., Bounded Ethicality as a Psychological Barrier to Recognizing Conflicts of Interest, in CONFLICTS OF INTEREST 74, 77 (Don A. Moore et al., eds., 2005) (arguing that conflicts of interest result not from "explicit dishonesty," but rather because "individuals view themselves as moral, competent, and deserving, and this view obstructs their ability to see and recognize conflicts of interest when they occur"); Don A. Moore \& George Loewenstein, SelfInterest, Automaticity, and the Psychology of Conflict of Interest, 17 Soc. JUST. RES. 189, 189 (2004) (applying a dual process model to explain how conflicts of interest arise between automatic self-interest and one's ethical and professional obligations to others). See infra notes 109-42 and accompanying text.

26. Mickens v. Taylor, 535 U.S. 162, 205 n.10 (2001) (Souter, J., dissenting). 
systematically to underestimate the existence and influence of conflicting interests. It concludes that lawyers tend to be poor judges of conflicts of interest, both prospectively when assessing whether a conflict does or will exist, and retrospectively when assessing whether there was a conflict that had an adverse effect on the quality of representation provided. The implications of these findings are addressed in Part IV, which reviews options to address the reality of how lawyers respond to conflicts in criminal cases. It concludes that, because lawyers are not well-suited to evaluate conflicting interests, a new approach is necessary to reduce the importance of the testimony of the lawyer whose conduct is under scrutiny when a conflict has been alleged.

\section{CONFLICTS OF INTEREST IN CRIMINAL CASES}

Identifying and resolving complex questions raised by conflicts of interest can be vexing, even for a highly competent lawyer. ${ }^{27}$ In criminal cases, where an attorney must often balance delicate and competing concerns, the possibility of a conflict is often present. The first challenge confronting the lawyer is to gather enough information from clients and other sources to determine whether a conflict exists or is likely. Next, the lawyer must apply the relevant ethical rules of professional conduct, which themselves are complex. This section reviews the types of situations that are ripe for conflicts in criminal cases - including cases of multiple representation, successive representation and conflicts arising from a lawyer's personal interests - and the ethical issues involved. It also reviews the Supreme Court's treatment of conflicts in criminal cases, with a focus on the Court's views about the competence of defense lawyers to resolve conflicts of interest that can arise, and the central role that testimony by defense counsel plays in post-conviction proceedings.

\section{A. Diagnosing Conflicts of Interest}

Like all lawyers, criminal defense attorneys are charged with the duty to identify and resolve conflicts of interest that occur during representation. Much of the challenge in exercising this professional

27. Many have described the complex nature of conflicts of interest. See, e.g., Nathan M. Crystal, Professional Responsibility: Problems of PRACTICE AND the Profession 148 (2d ed. 2000) ("Conflicts of interest present some of the most pervasive and difficult ethical problems that lawyers face in practice.”); STEPHEN GILLERS, REGULATION OF LAWYERS 230 (6th ed. 2002) ("It is probably safe to say that conflicts of interest present some of the most complex problems in the area of legal ethics."); W. BradLEy Wendel, Professional ReSPONSIBILITY 255 (2004) (describing the rules on conflicts as "intricate, technical, and arcane"). 
responsibility requires a lawyer to gather relevant information from clients and other relevant sources. For example, multiple representation ${ }^{28}$ - which by nature is rife with conflicts of interestrequires a lawyer to make exceedingly careful evaluations to determine whether conflict-free representation is possible. ${ }^{29}$ Does the evidence indicate that one defendant might be less culpable than others, creating the possibility that a plea bargain might benefit one defendant at the expense of others? Do the defendants have antagonistic defenses? Is it in the best interest of one defendant to testify, while another should remain silent, which might signal to the jury that the silent defendant has something to hide? These are just some of the questions that must be answered to determine whether an attorney can represent more than one defendant in a criminal proceeding. ${ }^{30}$

Even when the interests of the clients are aligned before trial, information that becomes known as the case proceeds can create a conflict that previously did not exist. For example, a lawyer who planned a joint defense strategy claiming that no defendant was involved in the crime might have to re-think the strategy if the trial evidence is much stronger against one defendant than others. Or the clients themselves might decide to disclose information not previously known to the attorney that creates an incongruity of interest. These and other

28. Multiple or joint representation refers to a situation where one lawyer represents two or more defendants who are jointly charged with criminal activity. See generally JOHN M. BURKOFF, CRIMINAL DEFENSE ETHICS: LAW AND LiABILITY $\S 6: 10$ (2004). Defense lawyers can also have conflicts caused by other simultaneous obligations. For example, a defense lawyer who simultaneously works as a part-time prosecutor, or whose fee is being paid by a third party, may have a conflict of interest. $I d$. $\S \S 6: 11,: 18$. For a good description of conflicts of interest in criminal cases, see Ethical Problems Facing the Criminal Defense Lawyer: Practical Answers to TOUGH QueSTIONS 233-308 (Rodney J. Uphoff ed., 1995).

29. Because of the significant risk of conflicts in cases of multiple representation, the Federal Rules of Criminal Procedure require trial courts to take steps to protect the rights of defendants. See FED. R. CRIM. P. 44(c)(2) ("The court must promptly inquire about the propriety of joint representation and must personally advise each defendant of the right to the effective assistance of counsel, including separate representation. Unless there is good cause to believe that no conflict of interest is likely to arise, the court must take appropriate measures to protect each defendant's right to counsel."). Other authorities have noted these dangers. See, e.g., MODEL RULES OF PrOF'L CONDUCT R.1.7 cmt. 23 (2008) ("The potential for conflict of interest in representing multiple defendants in a criminal case is so grave that ordinarily a lawyer should decline to represent more than one codefendant."); ABA Standards for Criminal Justice: The Prosecution Function and The Defense Function, $§ 4-3.5$ (c) (3d ed. 1993) (suggesting similar cautions).

30. For an excellent discussion of the types of situations that can give rise to conflicts of interest in cases of multiple representation, see John Stewart Geer, Representation of Multiple Criminal Defendants: Conflicts of Interest and the Professional Responsibilities of the Defense Attorney, 62 MiNN. L. REV. 119, 125-40 (1978); see also Green, supra note 22, at 1203-04. 
circumstances can change the calculations the lawyer must make in assessing the risk of conflict. ${ }^{31}$

Lawyers must also determine whether, as in Mickens, ${ }^{32}$ a conflict exists between current and former clients, a situation commonly known as the problem of successive representation. ${ }^{33}$ For example, if defense counsel previously represented the victim, or a witness who will be testifying for the prosecution, the lawyer must decide whether confidential information was gained in the prior representation. If so, will the former client testify to matters that would normally require the lawyer to use previously obtained confidential information as a source for cross-examination? ${ }^{34}$ Does the representation of the prior client make it harder for the defense attorney to seek a favorable plea bargain for the defendant? Or will the lawyer be able to represent the defendant's best interests despite the prior representation ? $^{35}$

Personal interests of the lawyer can also result in conflicts. For example, the lawyer must carefully assess whether the case will generate

31. Some have proposed a checklist of relevant circumstances a lawyer should investigate in deciding whether multiple representation is permissible. See Richard H. UnDERWOOD \& William H. ForTUNE, TRIAL ETHICS $§ 14.3 .1$ (1988) ("1. Is one defendant more culpable than the other? If so, conflict is almost inevitable, either because the prosecution will offer a deal to the one less culpable or because distinctions will need to be drawn during the case. 2. Are the defenses inconsistent in any way? 3. Will one testify and the other not? A defendant who testifies inevitably calls attention to the failure of the other defendant to take the stand. The problem is exacerbated by joint representation. 4. Will the prosecution's evidence strike the defendants unequally? If a prosecution witness implicates $A$ but not $B$, the attorney is put in the position of attacking the witness on behalf of $A$ but implying that he is telling the truth about $B$. 5. Should distinctions be drawn in closing argument? The attorney representing codefendants cannot do so. 6 . Should distinctions be drawn at sentencing, either because of relative culpability or the different backgrounds of the defendants?"); see also CRYSTAL, supra note 27, at 152 (quoting a similar version of the checklist).

32. See supra notes $4-17$ and accompanying text.

33. For the seminal discussion of conflicts of interest that can arise in cases of successive representation, see Gary T. Lowenthal, Successive Representation by Criminal Lawyers, 93 YALE L.J. 1 (1983); see also BURKOFF, supra note 28, at $\S$ 7:1-9.

34. As the Court noted in Moss v. United States:

The fear in successive representation cases is that the lawyer will fail to crossexamine the former client rigorously for fear of revealing or misusing privileged information. Thus, the most common example of an actual conflict of interest arising from successive representation occurs where an attorney's former client serves as a government witness against the attorney's current client at trial.

323 F.3d 445, 460 (6th Cir. 2003) (citations omitted).

35. There will, of course, be situations where the defense attorney need not utilize confidential information obtained from a former client to advance the interests of the current client. For example, the interests of the former and current clients may be aligned, meaning that there is no need to impeach the former client on the witness stand. In addition, even when the attorney is obligated to impeach the former client, the confidential information obtained during the prior representation may duplicate other information readily available, again making it unlikely that the lawyer will need to utilize the confidential information in cross-examination. Green, supra note 22, at 1219-20 nn.8687. 
media attention and, if so, whether the benefits of media exposure will create incentives for the lawyer that might be adverse to the interests of the defendant. ${ }^{36}$ Other personal interests, such as the economic incentive to secure attorney fees, ${ }^{37}$ can give rise to conflicts that need careful scrutiny. ${ }^{38}$

The difficulty in gathering information is compounded by the nature of a criminal proceeding. As the Supreme Court has noted, in criminal cases defendants may fail to provide complete and accurate versions of events to attorneys, especially at the early stages of representation when the attorney-client relationship has just been formed. ${ }^{39}$ The frequency with which information is hidden from lawyers is impossible to know; but, it is reasonable to assume that many lawyers will find it hard to gather all they need from a client when making a conflicts calculation and will, therefore, need to investigate other sources of information before making any final determination.

Once relevant information is obtained, the defense lawyer must decide whether, under the circumstances, there is a conflict under the governing rules of the profession-which in almost all jurisdictions are based on the Model Rules of Professional Conduct. ${ }^{40}$ As others have noted, except in those few situations where conduct is flatly prohibited, the duty in every case is to determine the degree of risk that the lawyer's ability to properly function will be impaired. ${ }^{41}$

The notion that conflicts are about assessing risk is at the foundation of the ethical rules. ${ }^{42}$ For example, under Model Rule 1.7, which

36. For the type of high profile case that could result in a conflict of interest, see Beets v. Scott, 65 F.3d 1258, 1261-62 (5th Cir. 1995) (defense attorney accepted reduced fee to represent a client accused of killing multiple former husbands in exchange for obtaining media rights to the case).

37. See, e.g., United States v. Schwarz, 283 F.3d 76, 91-92, 110 (2d Cir. 2002) (reversing conviction where defense counsel was paid by police union to represent police officers accused of crimes).

38. The Model Rules of Professional Conduct ("Model Rules") provides a list of situations that can give rise to conflicts caused by the personal interests of the lawyer. MODEL RULES OF PROF'L CONDUCT R. 1.8. See also BURKOFF, supra note 28, at $\S \S 6: 13-16$. Most commentators agree that the Model Rules provide a better formulation of conflicts of interest than did earlier sources of regulatory authority. See Fred C. Zacharias, Waiving Conflicts of Interest, 108 YALE L.J. 407, 407 n.2 (1998).

39. Wheat v. United States, 486 U.S. 153, 162-63 (1988).

40. Only California has resisted adopting a version of the Model Rules. See ABAnet.org, Model Rules of Professional Conduct: Dates of Adoption, http://www.abanet.org/cpr /mrpc/chron_states.html (last visited Aug. 21, 2009) (listing the jurisdictions adopting a version of the Model Rules).

41. See 1 Geoffrey C. Hazard, JR. \& W. William Hodes, The LaW of LaWyering $\S 10.4$ (2004); Kevin McMunigal, Rethinking Attorney Conflicts of Interest Doctrine, 5 GEO. J. LEGAL ETHICS 823, 874 (1992).

42. The rules governing professional conduct define the circumstances that can give rise to 
governs conflicts with current clients, a conflict exists when "there is a significant risk that the representation of one or more clients will be materially limited by the lawyer's responsibilities to another client, a former client or a third person or a personal interest of the lawyer., ${ }^{43}$ Situations involving successive representation also involve risk assessment. Under Model Rule 1.9, a lawyer must determine whether representation of a former client was "substantially related" to representation of the current client's matter, which in turn requires analysis of whether "there is a substantial risk that confidential factual information as would normally have been obtained in the prior representation would materially advance the client's position in the subsequent matter." 44 If so, and the interests of the current and former clients are materially adverse, a conflict exists. ${ }^{45}$

The Restatement of the Law Governing Lawyers combines the rules relating to conflicts of interest into a single standard that focuses on risk. "A conflict of interest is involved if there is a substantial risk that the lawyer's representation of the client would be materially and adversely affected by the lawyer's own interests or by the lawyer's duties to another current client, a former client, or a third person." 46

The inquiry whether a conflict exists under this formulation is measured according to an objective standard, meaning that a lawyer's conclusions will be evaluated based on the "facts and circumstances that the lawyer knew or should have known at the time of undertaking or continuing a representation." 47

disciplinary proceedings against attorneys. They do not define the standard of care owed to a client for the purpose of assessing professional malpractice, or whether a defendant received effective assistance of counsel. See MOdel RULES OF PROF'L CONDUCT, Preamble and Scope cmt. 20 (2008); BURKOFF, supra note 28, $\S \S 1.7,2.9-10$.

43. Model Rules OF PROF'L CONDUCT R. 1.7(a)(2).

44. Id. cmt. 3. For a list of states that have adopted the comments to the Model Rules, see ABAnet.org, ABA Model Rules of Professional Conduct, http://www.abanet.org/cpr $/ \mathrm{mrpc} /$ model_rules.html (last visited Aug. 25, 2009).

45. See Model Rules of Prof'L Conduct R. 1.9(a) (2008). As currently drafted, there is some confusion whether a former client who is a witness against a current client in a criminal proceeding can be said to be "adverse" so as to invoke the prohibitions of Rule 1.9. See Green, supra note 22, at 1217-19. Most courts have concluded that there is adversity simply because the former client will be testifying against the interests of the present client. Id.

46. 2 RESTATEMENT (THIRD) OF THE LAW GOVERNING LAWYERS § 121 (2001). According to the comment, under the Restatement an "adverse" effect refers to the "quality of the representation, not necessarily the quality of the result obtained in a given case." Id. $\S 121 \mathrm{cmt}$. c(i). In other words, a conflict will exist when there is sufficient risk that divided loyalties or interests will adversely affect representation, irrespective of whether the feared result occurs.

47. Id. $\S 121 \mathrm{cmt}$. c(iv). Given the risks involved in multiple representation of defendants by a single lawyer, the Restatement concludes that multiple representation always constitutes a conflict of interest that is prohibited, unless all affected clients provide informed consent. Id. § 129. 
Placing risk at the center of conflicts analysis results in an important point that can be overlooked: as a matter of professional ethics, a conflict of interest exists even if the feared eventuality never materializes. In other words, a conflict is present if there is sufficient risk of resulting impairment, irrespective of whether the lawyer's ability to function is ever adversely affected by the circumstances. ${ }^{48}$ A lawyer who determines that the risk of conflict is sufficient to trigger the prescriptions of the ethical rules must, therefore, resolve the ethical matter at the time the risk becomes realized, and not wait until representation becomes compromised. This standard of conduct stands in stark contrast to the standard governing post-conviction claims of ineffective assistance of counsel under the Sixth Amendment, which in most cases requires proof that the lawyer's conduct was, in fact, adversely affected by the circumstances that produced the conflicting interests. $^{49}$

Once a conflict is identified, the lawyer's work is not done. In some instances, it may be in the client's best interest to waive the conflict to permit the lawyer to continue representation in the matter. ${ }^{50}$ The lawyer must decide whether the conflict is the type that can be waived, ${ }^{51}$ and if so must obtain the client's informed consent, ${ }^{52}$ which requires sufficient information so that the client can evaluate both the material risks involved and the alternatives that are available. ${ }^{53}$ This includes determining whether, despite the conflict, the lawyer can competently and diligently represent the client, ${ }^{54}$ and whether informed consent can be obtained from the affected clients in writing. ${ }^{55}$

48. See HAZARD, JR. \& HodES, supra note 41, §10-12 ("In the modern view, a conflict of interest exists whenever the attorney-client relationship or the quality of the representation is 'at risk,' even if no substantive impropriety - such as the breach of confidentiality or less than zealous representation - in fact eventuates."). For the seminal discussion of these issues, see McMunigal, supra note 41, at 826-33; see also Kevin C. McMunigal, Comment: Multi-Disciplinary Practice and Conflict of Interest, 52 CASE W. RES. L. REV. 995, 999 (2002).

49. See infra notes 72-77 and accompanying text.

50. For a good discussion of the many issues involved in waiving conflicts of interest, see Zacharias, supra note 38 , at 436.

51. See id. at 1.7(b)(3); Model Rules OF Prof'L CONDUCT R. 1.7(b) (2008) (stating when the conflict cannot be waived no matter the client's wishes).

52. Id. R. 1.7(b)(4), 1.9(a).

53. See id. R. 1.7(b) \& 1.9(a); R. 1.0(e) (stating informed consent "denotes the agreement by a person to a proposed course of conduct after the lawyer has communicated adequate information and explanation about the material risks of and reasonably available alternatives to the proposed course of conduct").

54. Id. R. 1.7(b)(1). A conflict cannot be waived when the representation requires one client to assert a claim against another client in the same proceeding. Id. R. 1.7(b)(3).

55. Id. R. 1.7(b)(4). 
In sum, a lawyer in a conflicts situation faces multiple complex tasks. The rules of professional conduct assume that lawyers can, through rational deliberation, make these assessments competently. But do others make the same assumption? As the next section discusses, the Supreme Court has adopted standards in conflicts cases that rely on inconsistent views about the abilities of defense lawyers to address and resolve conflicts of interest that arise during representation in criminal cases.

\section{B. Supreme Court Jurisprudence}

The Supreme Court has addressed three interrelated questions concerning conflicts of interest in criminal cases, each of which focuses on the Sixth Amendment right to effective assistance of counsel. ${ }^{56}$ First, what amount of discretion should a trial court possess in deciding whether to disqualify a defense lawyer because of a conflict of interest? Second, under what circumstances does the trial court have a duty to inquire whether the defense attorney has a conflict of interest? Third, what must a defendant prove to obtain relief from a conviction based on a conflict of interest?

The answers to these questions reveal the Court's opinion about the abilities and willingness of defense lawyers to resolve conflicts of interest in criminal cases. Curiously, the Court has expressed inconsistent views - on the one hand showing little confidence in defense lawyers to resolve conflicts when defining the rules that apply prospectively, that is, when a conflict is alleged before or during representation; on the other hand, concluding that defense attorneys are well-suited to resolve conflicts when defining the rules that apply retrospectively, that is, when a defendant brings a post-conviction claim of ineffective assistance of counsel.

\section{Skepticism About Defense Attorneys}

The Supreme Court expressed skepticism about the abilities of defense lawyers in Wheat $v$. United States, ${ }^{57}$ the case that decided the amount of discretion trial courts possess to disqualify defense lawyers on conflict grounds. ${ }^{58}$ The prosecutor in Wheat objected to the defendant's

\footnotetext{
56. See infra notes $57-84$ and accompanying text.

57. 486 U.S. 153 (1988).

58. Id. at 163 .
} 
request to retain a lawyer, arguing that the lawyer had a conflict of interest. ${ }^{59}$ The defendant was willing to waive the conflict, which defense counsel claimed the prosecution had manufactured for tactical advantage. ${ }^{60}$ Concerned about what it called a "whip-saw" effectwhereby the defendant asserts a right to waive a conflict before trial but then asserts after trial that the conflict rendered assistance of counsel ineffective - the Court concluded that trial courts must be afforded "substantial latitude" in deciding whether to accept waivers in cases where there is either an "actual" or "potential" conflict of interest. ${ }^{61}$

In coming to this conclusion, the Court in Wheat derided the ability of defense attorneys to assess and resolve conflicts of interest. According to the Court, conflicts are "notoriously hard to predict" in the pre-trial stage of proceedings, both because clients often fail to disclose the entire truth to their attorneys and because the disclosure of new facts can change the calculus at any time. ${ }^{62}$ As a result of these "imponderables," the Court stated that attorneys will find it "difficult" to assess the risk of conflict "and even more difficult" to communicate those risks effectively to a client who must make the waiver decision. ${ }^{63}$ In addition, the Court stated that attorneys who are willing to seek waivers may fail to take appropriate care in communicating all of the

59. Id. at 155 . The defendant in Wheat was charged, along with other co-defendants, in a large scale drug conspiracy. Id. at 154. An attorney named Iredale represented two of the co-defendants, both of whom agreed to plead guilty. Id. at 155 . Shortly before the defendant's trial, the defendant sought to hire Iredale as counsel. Id. The prosecution objected, claiming that Iredale had a conflict of interest, principally because one of Iredale's other clients might be called as a witness in the defendant's trial. $I d$. at 156 . The prosecution also claimed that the defendant might be required to testify against another of Iredale's clients if plea negotiations that were under way broke down. Id. at $155-56$.

60. Id. at 157. For criticism of the Court's analysis of the likelihood of a conflict under these facts, see Green, supra note 22, at 1221-22 (concluding that the Court misunderstood the ethical rules); see also Michael E. Lubowitz, Note, The Right to Counsel of Choice After Wheat v. United States: Whose Choice Is It?, 39 AM. U. L. REV. 437, 439 (1990) ("Following Wheat, a defendant's waiver of the right to conflict-free counsel, in favor of a particular attorney, can be denied for purely speculative reasons.").

61. Wheat, 486 U.S. at 163; see also United States v. Gonzalez-Lopez, 548 U.S. 140, 147 n.3, 150 (2006) (noting that violations of the right to counsel of choice are structural, requiring no proof of prejudice, but reaffirming that trial courts retain broad discretion to disqualify counsel based on a conflict of interest). Wheat did not define the line that divides "actual" versus "potential" conflicts of interest. Elsewhere, the Court has concluded that an "'actual conflict,' for Sixth Amendment purposes, is a conflict of interest that adversely affects counsel's performance." Mickens v. Taylor, 535 U.S. 162, 172 n.5 (2002). For criticism of the linguistic distinction between "potential" and "actual" conflicts, see McMunigal, supra note 41, at 846-47; MONROE H. FrEedMAN \& ABBE SMITH, UNDERSTANDING LAWYERS' ETHICS, § 10.10 (3d ed. 2004).

62. Wheat, 486 U.S. at $162-63$. Others have also described the natural tendency of defendants to insist on their innocence, even when there is strong evidence to the contrary, at the early stages of representation. See FREEDMAN \& SMITH, supra note 61, § 10.10.

63. Wheat, 486 U.S. at 163. 
salient facts of the situation. ${ }^{64}$ While the Court did not expound upon this accusation, one possibility is that the Court was suggesting that a lawyer who has a conflict of interest will be motivated by economic incentives to encourage waiver whenever possible. ${ }^{65}$ Together, these views indicate distrust that lawyers can identify conflicts and communicate about them in a way that protects the rights of defendants. ${ }^{66}$

\section{Optimism About Defense Attorneys}

In contrast to Wheat, the Supreme Court has made favorable comments about defense lawyers in a series of cases defining the standards that apply when a defendant seeks post-conviction relief under the Sixth Amendment. For example, in Holloway v. Arkansas, ${ }^{67}$ the defendant sought relief from a conviction because the trial court had forced his attorney to represent multiple defendants with incongruent interests. The Supreme Court concluded that defense attorneys are "in the best position professionally and ethically to determine when a conflict of interest exists or will probably develop in the course of a trial.",68 In addition, the Court noted that lawyers have ethical obligations to bring conflicts to the trial court's attention ${ }^{69}$ and can be relied upon to do so truthfully because, as officers of the court, they make statements effectively "under oath."70 The Court then created a bright-line rule: when defense counsel objects to representing multiple

\section{Id.}

65. A number of Supreme Court justices have made similar suggestions in other cases. See, e.g., Mickens v. Taylor, 535 U.S. 162, 204-05 (2002) (Souter, J., dissenting) (noting reason to believe that defense counsel suppressed the conflict of interest for sake of a fee and publicity surrounding the case); Burger v. Kemp, 483 U.S. 776, 806 n.11 (1987) (Blackmun, J., dissenting) (noting that the defense lawyer may have ignored a conflict because he had an interest in preserving his ability to obtain future fees); see also Green, supra note 22, at 1228 (noting that "a retained attorney's financial stake in the representation may create a disincentive to comply with the particular standards governing conflicts"); Lowenthal, supra note 33, at 37 (making the same argument and citing lower court opinions on point).

66. See Green, supra note 22 , at 1228.

67. 435 U.S. 475 (1978).

68. Id. at 485 (emphasis added) (citing State v. Davis, 514 P.2d 1025, 1027 (Ariz. 1973)). While the Court did not explain this conclusion, one possibility is that the defense attorney may be the only person with access to confidential information needed to decide whether a conflict exists or is likely.

69. Id. at 485-86 (citing ABA STANDARDS RELATING TO THE ADMINISTRATION OF CRIMINAL Justice, THE DEFENSE FunCTION $§ 3.5(\mathrm{~b})$ (1974)).

70. Id. at 486. The Court rejected the notion advanced by the prosecution that "unscrupulous" defense attorneys would mislead trial courts into believing that non-existent conflicts were present. Id. 
clients with conflicting interests, the trial court must, at a minimum, inquire into the basis of the defense objection and the failure to do so will result in automatic reversal of any resulting conviction. ${ }^{71}$

In Cuyler v. Sullivan, ${ }^{72}$ where one defense attorney was hired to represent multiple defendants in different proceedings, but who did not object that there was a conflict of interest, the Court reiterated its view that attorneys are in the "best position" to resolve conflicts and are ethically obligated to do so. ${ }^{73}$ In addition, the Court noted that trial courts must "necessarily rely in large measure upon the good faith and good judgment of defense counsel" in assessing whether a conflict exists or will arise. ${ }^{74}$ The Court then concluded that a trial court will be required to inquire whether a conflict exists only when defense counsel informs the court of a conflict, or when other circumstances put the court on notice that a particular conflict is present. ${ }^{75}$ In addition, when defense counsel does not object, any subsequent conviction will be reversed only when the defendant can prove that there was an "actual conflict of interest" that "adversely affected his lawyer's representation."76 This "adverse effects" test, as it is known, is qualitatively different than the standard under the ethical rules of the profession, which assess only the risk of impairment and not the actual effect that a conflict has on the representation provided. ${ }^{77}$

71. Id. at 484-89 (citing Glasser v. United States, 315 U.S. 60 (1942)) (noting Glasser was the Court's earliest decision addressing the constitutional implications of conflicts of interest). In Glasser, the Court concluded that the Sixth Amendment protects a defendant who was forced to receive representation by a lawyer with a conflict of interest. Holloway, 435 U.S. at $484-85$. For a good discussion of Glasser and its implications for the Court's conflicts jurisprudence, see Green, supra note 22, at 1204-06.

72. 446 U.S. 335 (1980).

73. Id. at 347 (quoting Holloway, 435 U.S. at 485).

74. Id. See Burger v. Kemp, 483 U.S. 776, 784 (1987) (expressing similar views in a case where two law partners represented defendants who had been jointly indicted but separately tried for the same crime). In identifying the applicable standard of proof, the Burger Court noted that it "generally presume[s]" that a defense lawyer "is fully conscious of the overarching duty of complete loyalty to his or her client." Id.

75. Sullivan, 446 U.S. at $346-48$.

76. Id. at 350. The Court left open the question, since resolved in Mickens, whether the adverse effects test applied in cases where, although there was no defense objection, the trial court knew or should have known about a conflict. See infra notes 78-82 and accompanying text.

77. See supra notes 41-48 and accompanying text. Strickland v. Washington, 466 U.S. 668 , 695 (1984) (defining the standard for most cases alleging ineffective assistance of counsel). Under the Strickland test, a defendant who is seeking post-conviction relief must prove that defense counsel's conduct was objectively unreasonable and that, but for counsel's deficient performance, there is a reasonable probability that the result of the proceeding would have been different. Id. For a sampling of the criticism of the Strickland test, see Primus, supra note 3, at $684 \mathrm{n} .24$ (collecting critical commentary of the Strickland test); Fred C. Zacharias, Structuring the Ethics of Prosecutorial Trial Practice: Can Prosecutors Do Justice?, 44 VAND. L. REV. 45, 67 n.98 (1991) (same). For a particularly strong condemnation of the Strickland standard in death penalty cases, see 
Most recently, in Mickens v. Taylor ${ }^{78}$ the issue before the Court was whether a defendant must meet the Sullivan adverse effects test when there was no defense objection, but the trial court knew or should have known of a potential conflict of interest from another source. ${ }^{79}$ Based upon its assessment of precedent, ${ }^{80}$ the Court concluded that the Holloway automatic reversal standard is appropriate only when the trial court ignores a defense objection. In all other cases, even when the trial court knows about a likely conflict, the defendant must prove that an actual conflict of interest had an adverse effect on the quality of representation provided. ${ }^{81}$ In coming to this conclusion, the Court again

Stephen B. Bright, Counsel for the Poor: The Death Sentence Not for the Worst Crime but for the Worst Lawyer, 103 YALE L.J. 1835 (1994).

78. 535 U.S. 162 (2002).

79. Id. at 164. It was undisputed that the judge who appointed the defense attorney in Mickens knew or should have known that there was a potential conflict of interest. Id. at 165 .

80. Much of the discussion in Mickens involved interpretation of a remand order in Wood $v$. Georgia, a case where a conflict of interest had been alleged during a probation-revocation hearing. 450 U.S. 261, 262-63 (1981). Justice Scalia, writing for the majority in Mickens, concluded that the order remanding the case in Wood supported the conclusion that the Sullivan adverse effects test applied in any case where defense counsel did not raise an objection that a conflict of interest was present. Mickens, 535 U.S. at 169-72. The dissenting justices in Mickens disagreed, arguing that Wood supported the position that the Holloway automatic reversal standard should apply in any case where the trial court knew or should have known that a conflict was present. Id. at 186-87 (Stevens, J., dissenting); id. at 195-202 (Souter, J., dissenting).

81. Mickens, 535 U.S. at 174. Justice Scalia suggested in dicta that a more rigorous standard of proof than the Sullivan adverse effects test might be appropriate in cases other than multiple representation. Id. at 175-76. Lower federal courts have disagreed on this issue: some have concluded, or at least assumed, that the Sullivan adverse effects test applies to all conflicts cases, even when multiple representation is not alleged. See, e.g., United States v. DeCologero, 530 F.3d 36 (1st Cir. 2008), cert. denied, 129 S. Ct. 513 (2008) (applying Sullivan adverse effects test where defense counsel's law partner represented a defense witness); United States v. Stitt, 441 F.3d 297, 303 (4th Cir. 2006) ("we have concluded on multiple occasions that the Sullivan presumption applies, even when counsel is not simultaneously representing two or more persons"), vacated on other grounds, 459 F.3d 483 (4th Cir. 2006); United States v. Fuller, 312 F.3d 287, 292 (7th Cir. 2002) (assuming that Sullivan adverse effects test applies to conflict caused by defense counsel's alleged desire to shield himself from malpractice claim); Campbell v. Rice, 302 F.3d 892, 896-97 (9th Cir. 2002) (applying Sullivan adverse effects test where defense counsel and defendant were simultaneously being prosecuted by the same prosecutor's office); Winkler v. Keane, 7 F.3d 304, 307 (2d Cir. 1993) (applying Sullivan adverse effects test to a conflict of interest caused by contingency fee agreement); Graffia v. United States, 264 F. Supp. 2d 674, 679 (N.D. Ill. 2003) (applying Sullivan adverse effects test to a case where defense counsel had an alleged conflict based on prior employment as a prosecutor). Other courts have concluded that the question is still open. See, e.g., Schwab v. Crosby, 451 F.3d 1308, 1327-28 (11th Cir. 2006) (concluding, for the purposes of federal habeas corpus review, that the law is not settled as to whether the Sullivan adverse effects test applies to a purported conflict based on an attorney's personal interests); Smith v. Hofbauer, 312 F.3d 809, 817-18 (6th Cir. 2002) (noting that, for purposes of federal habeas review, there is no clearly established law to extend the Sullivan adverse effects test to situations other than multiple representation). Finally, some courts have concluded that the Sullivan adverse effects test applies only to cases of multiple representation. See, e.g., Beets v. Scott, 65 F.3d 1258, 1266 (5th Cir. 1995) (concluding that one cannot read Sullivan in a broader context than multiple client representation). For discussion of these various positions, see Shiner, supra note 4, at 980-96. 
reiterated that defense attorneys are in the best position to determine conflicts, are ethically obligated to do so, and essentially make statements under oath. ${ }^{82}$

As this review of Supreme Court jurisprudence demonstrates, the Court has spoken inconsistently on whether defense attorneys are wellsuited to address and resolve conflicts of interest that can arise in criminal cases. While others have noted these competing views, ${ }^{83}$ no one has yet explored whether there is empirical support for the Court's claims. Section II tackles this open question by reviewing available empirical data about the corrosive effects of conflicts of interest on decision-making and judgment.

\section{Defense Lawyer Testimony}

A related question is whether a defense attorney who is accused of ineffectiveness due to a conflict of interest can be expected to testify accurately about decisions made during representation. This question is important because attorneys accused of ineffectiveness often play a central role in claims for post-conviction relief. While this point may seem obvious, some explanation is helpful.

While the Supreme Court has not defined with precision the elements of the Sullivan adverse effects test, lower courts have interpreted it in slightly different ways. Most require that the defendant prove that there was an alternative defense strategy not pursued by defense counsel that was either "inherently" in conflict with the strategy that counsel did pursue, or that defense counsel did not pursue an alternative strategy because of the conflict of interest. ${ }^{84}$ In other words, the defendant must prove causation - that the conflict caused defense counsel to forego an identifiable alternative strategy. Other courts add an additional requirement - that the alternative strategy be "objectively

82. Mickens, 535 U.S. at $167-68$.

83. See Green, supra note 22, at 1226-27.

84. See, e.g., United States v. DeCologero, 530 F.3d 36, $76-77$ (1st Cir. 2008) (defendant must show an alternative strategy was plausible and was in conflict with the attorney's "other loyalties or interests"), cert. denied 129 S. Ct. 513 (2008); United States v. Infante, 404 F.3d 376, 392-93 (5th Cir. 2005) (adverse effect on counsel's performance when "counsel's judgment was actually fettered by concern over the effect of certain trial decisions on other clients"); Hess v. Mazurkiewicz, 135 F.3d 905, 910 (3d Cir. 1998) (defendant must show an alternative strategy was plausible and was in conflict with the attorney's "other loyalties or interests"); United States v. Levy, 25 F.3d 146, 157 (2d Cir. 1994) (same). Slight variations on this test have been developed. See, e.g., Sanders v. Ratelle, 21 F.3d 1446, 1452 (9th Cir. 1994) (holding that if the defendant's attorney had a conflict of interest, the defendant must show that "some effect on counsel's handling of particular aspects of the [case] was “likely"” (citing United States v. Miskinis, 966 F.2d 1263, 1268 (9th Cir. 1992))). 
reasonable" under the facts and circumstances known to the attorney at the time that tactical decisions in the defendant's case were made. ${ }^{85}$

Whichever test is employed, proof from outside the record will be necessary in most cases. ${ }^{86}$ As the Supreme Court noted in Holloway, a conflict of interest is pernicious most often because of what it causes a lawyer to refrain from doing, rather than what it causes a lawyer to do. ${ }^{87}$ For example, in a case of multiple representation, a conflict may prevent defense counsel

from exploring possible plea negotiations and the possibility of an agreement to testify for the prosecution, provided a lesser charge or a favorable sentencing recommendation would be acceptable. Generally speaking, a conflict may also prevent an attorney from challenging the admission of evidence prejudicial to one client but perhaps favorable to another, or from arguing at the sentencing hearing the relative involvement and culpability of his clients in order to minimize the culpability of one by emphasizing that of another. Examples can be readily multiplied. ${ }^{8}$

Such omissions, "by their very nature, do not appear on the record and thus, require further fact-finding, extra-record investigation and where necessary, an evidentiary hearing." $" 89$

Ironically, the person likely to know the most about what transpired during representation of the defendant - and in particular about the reasons why certain decisions were made - is the lawyer whose conduct is alleged to have been ineffective. This creates an interesting dynamic,

85. E.g., United States v. Nicholson, 475 F.3d 241, 251-52 (4th Cir. 2007); Covey v. United States, 377 F.3d 903, 908 (8th Cir. 2004); Quince v. Crosby, 360 F.3d 1259, 1264-65 (11th Cir. 2004); see also United States v. Bowie, 892 F.2d 1494, 1500 (10th Cir. 1990) (defendant must prove there was a "specific and seemingly valid or genuine alternative strategy or tactic inherently in conflict with his duties to others or to his own personal interests.").

86. See Massaro v. United States, 538 U.S. 500, 503-05 (2003) (collateral review is better suited to resolve claims of ineffectiveness, such as alleged conflicting interests); Kimmelman v. Morrison, 477 U.S. 365, 378 (1986) (collateral review is frequently the only avenue through which a defendant can bring a successful claim of ineffective assistance of counsel); see also Primus, supra note 3, at 688-90 (explaining most jurisdictions require a defendant to raise ineffectiveness claims through collateral proceedings rather than direct appeal); Donald A. Dripps, Ineffective Litigation of Ineffective Assistance Claims: Some Uncomfortable Reflections on Massaro v. United States, 42 BRANDEIS L.J. 793, 796-97 (2004) (concluding that "[t]he heart of [Massaro v. United States] is that ineffective assistance claims typically cannot be litigated effectively on direct appeal.").

87. Holloway v. Arkansas, 435 U.S. 475, 490 (1978).

88. Id.

89. Commonwealth v. Grant, 813 A.2d 726, 736 (Pa. 2002); see also Primus, supra note 3, at 689 
where the defense lawyer whose conduct is under scrutiny will often be the most important witness at the collateral proceeding. ${ }^{90}$

Mickens is again illustrative. While most of the discussion in the Supreme Court was about interpretation of precedent, ${ }^{91}$ Justice Kennedy, whose concurring opinion provided the two crucial votes to affirm the conviction, focused on the testimony of the defense attorney, Bryan Saunders. Applying the required deferential standard of review, Justice Kennedy was not persuaded to disturb the district court's credibility findings that "Saunders did not believe he had any obligation to his former client," or that Saunders's "prior representation did not influence the choices he made during the course of the trial." 92 On the issue of consent, Justice Kennedy concluded, as did the district court, that the defense was foreclosed by the defendant's insistence on his own innocence. ${ }^{93}$

In contrast, in Sullivan, the testimony of defense counsel was sufficient to meet the adverse effects test. The defendant there sought habeas relief claiming that his attorneys had a conflict of interest caused by multiple representation. ${ }^{94}$ During an evidentiary hearing on the issue, one of the attorneys accused of ineffectiveness admitted that the defense team did not present evidence beneficial to the defendant because of

90. Others have noted the importance of the testimony of defense counsel in post-conviction proceedings to determine ineffective assistance of counsel. See David M. Siegel, My Reputation or Your Liberty (or Your Life): The Ethical Obligations of Criminal Defense Counsel in Postconviction Proceedings, 23 J. Legal PROF. 85, 88 (1999) (noting that a lawyer who testifies about his or her own ineffectiveness "is not simply a witness. The lawyer is often the most significant and potentially valuable witness the former client may have to demonstrate ineffective assistance, and the lawyer's cooperation may dramatically assist the former client's claim.") (footnote omitted); Susan P. Koniak, Through the Looking Glass of Ethics and the Wrong with Rights We Find There, 9 GEO. J. LEGAL ETHICS 1, 7 (1995) (noting that only the defendant and defense counsel are competent to discuss the strategic decisions made during representation, and that an allegation of ineffectiveness will be "unlikely to succeed" when the attorney whose conduct is under review "vigorously contests" the claim).

91. See supra text of note 80 .

92. Mickens v. Taylor, 535 U.S. 162, 177 (2002) (Kennedy, J., concurring) (noting that the district court's findings would be upheld unless "clearly erroneous").

93. Id. at 179. Justice Kennedy also questioned the evidentiary basis for a defense of consent. Id. Like the district court, Justice Kennedy did not address whether a non-conflicted attorney who had thoroughly investigated a consent defense could have convinced Mickens to change the defense strategy, or, through investigation, could have found evidence to buttress the consent defense. See supra note 15 and accompanying text.

94. The three co-defendants accused of murder had been represented by the same two attorneys, although each defendant was tried separately. Cuyler v. Sullivan, 446 U.S. 335, 337-38 (1980). The defendant was tried first and convicted, whereas the two other co-defendants were later acquitted. $I d$. at 338. Although the defendants were tried separately, the Supreme Court concluded that the case involved multiple representation of defendants for conflicts purposes. Id. at 342 . 
loyalties owed to another co-defendant. ${ }^{95}$ Based on this testimony, the Third Circuit Court of Appeals concluded, on remand from the Supreme Court, that "it is clear that the attorneys failed to put forth their best case for [the defendant]. There is no question that their performance was less than it would have been had they not been representing [the codefendant] as well." ${ }^{96}$ As a result, habeas corpus was granted. ${ }^{97}$

These and other cases ${ }^{98}$ demonstrate that defense attorney testimony is often essential to resolving allegations of ineffectiveness. Yet, the question remains whether an attorney accused of ineffective assistance of counsel can be expected to testify accurately in post-conviction proceedings. ${ }^{99}$ The answer to this question lies in the empirical evidence, as discussed in the next section.

95. The defendant's lawyer in post-conviction proceedings admitted that the decision not to call the co-defendant, which could have undermined a key prosecution witness against the defendant, was motivated by the desire to protect the witness from self-incrimination. See Cuyler v. Sullivan, 723 F.2d 1077, 1087 (3d Cir. 1983).

96. Id. Burger v. Kemp, 483 U.S. 776 (1987) (providing another example where the testimony of the defense attorney was critical to the determination of whether a conflict of interest rendered assistance of counsel ineffective). In Burger, the defendant, who was sentenced to death, sought post-conviction relief, claiming that his trial attorney had a conflict of interest because the codefendant in the case, who had been tried separately, had been represented by the defense attorney's law partner. Id. at 781. There was no dispute that the two attorneys discussed strategies and research in preparing their defenses and that defense counsel authored appellate briefs for both the defendant and co-defendant. Id. In post-conviction proceedings, the attorney with the alleged conflict testified about the strategic reasons for decisions made on behalf of the defendant, including that he did not tailor his defense in any way to protect the co-defendant. Based in large measure on this testimony, the Supreme Court concluded that there was no conflict of interest that resulted in an adverse effect on the representation provided. Id. at 780-88.

97. Cuyler, 723 F.2d at 1087.

98. See, e.g., Fitzpatrick v. McCormick, 869 F.2d 1247, 1253 (9th Cir. 1989) (concluding, based on testimony of defense counsel, that defendant met burden of proof to establish an actual conflict of interest); Hammon v. Miller, No. CIV-04-1007-HE, 2008 WL 2740994, at *1 (W.D. Okla. July 10, 2008) (based on testimony of both trial counsel and appellate counsel, the district court concluded that defendant failed to establish actual conflict of interest). Of course, defense attorney testimony can also be critical when other types of deficiencies in representation are alleged. See, e.g., Florida v. Nixon, 543 U.S. 175, 192 (2004) (concluding, based on testimony of defense counsel, that the decision to concede guilt in death penalty case was objectively reasonable under the circumstances); Weeks v. Snyder, 219 F.3d 245, 258-59 (3d Cir. 2000) (crediting testimony of defense counsel as a reason to deny ineffectiveness claim where defendant claimed that his attorney had failed to advise him about the importance of certain evidence).

99. Some courts have concluded that defense attorneys should not be relied upon when a conflict of interest is alleged. See sources cited supra note 21; see also Sanders v. Ratelle, 21 F.3d 1446, 1452 (9th Cir. 1994) ("The existence of an actual conflict cannot be governed solely by the perceptions of the attorney; rather, the court itself must examine the record to discern whether the attorney's behavior seems to have been influenced by the suggested conflict."). 


\section{THE PSYCHOLOGY OF CONFLICTS OF INTEREST}

The assumption that lawyers in criminal cases can, through rational deliberation, identify and resolve conflicts of interest, and testify accurately about them, needs to be reassessed. For decades, experts in decision-making theory have explored the psychological processes that limit rational behavior. ${ }^{100}$ The insights from this field of study, known generally as behavioral economics, ${ }^{101}$ have caused many commentators to reevaluate legal doctrine in a variety of contexts. ${ }^{102}$ More recently, this research has been applied to the process by which ethical judgments are made, including assessments professionals make in the exercise of their ethical responsibilities. ${ }^{103}$ Conflicts of interests have received particular scrutiny, in large measure because of the role that conflicts played in major corporate scandals such as the collapse of Enron and

100. See Jeremy A. Blumenthal, Emotional Paternalism, 35 FLA. ST. U. L. REV. 1, 2 n.2 (2007) (noting developments over the last five decades). For a sampling of some of the major works in this area, including discussions on the ongoing debate about the validity of this form of interdisciplinary work, see Behavioral LaW And Economics (Cass R. Sunstein ed., 2000); Christine Jolls et al., A Behavioral Approach to Law and Economics, 50 STAN. L. REV. 1471 (1998); Donald C. Langevoort, Behavioral Theories of Judgment and Decision Making in Legal Scholarship: A Literature Review, 51 Vand. L. ReV. 1499 (1998); Jeffrey J. Rachlinski, The "New" Law and Psychology: A Reply to Critics, Skeptics, and Cautious Supporters, 85 CORNELL L. REV. 739 (2000); Symposium, Empirical Legal Realism: A New Social Scientific Assessment of Law and Human Behavior, 97 Nw. U. L. REV. 1075 (2003).

101. Other descriptive terms include "'behavioralism, behavioral law and economics,' . . ' the new law and psychology,' 'legal decision theory,' or 'law and behavioral science."' Jeremy A. Blumenthal, Law and the Emotions: The Problems Of Affective Forecasting, 80 IND. L.J. 155, 159 (2005).

102. For a sampling of the application of behavioral economics to legal study, see Tom Baker et al., The Virtues of Uncertainty in Law: An Experimental Approach, 89 IowA L. REV. 443 (2004) (criminal law); Oren Bar-Gill, The Behavioral Economics of Consumer Contracts, 92 MinN. L. REV. 749 (2008) (contract law); John Bronsteen et al., Hedonic Adaptation and the Settlement of Civil Lawsuits, 108 Colum. L. ReV. 1516 (2008) (civil litigation and settlement theory); Dennis D. Crouch, The Patent Lottery: Exploiting Behavioral Economics for the Common Good, 16 GEO. MASON L. Rev. 141 (2008) (intellectual property); Alon Harel \& Uzi Segal, Criminal Law and Behavioral Law and Economics: Observations on the Neglected Role of Uncertainty in Deterring Crime, 1 AM. L. \& ECON. REv. 276 (1999) (criminal law); Jolls et al., supra note 100 (tort law); Jeffrey J. Rachlinski, Gains, Losses, and the Psychology of Litigation, 70 S. CAL. L. REV. 113, 118 19 (1996) (civil litigation and settlement theory); Colleen M. Seifert, Now Why Didn't I Think of That? The Cognitive Processes that Create the Obvious, 12 LEWIS \& CLARK L. REV. 489 (2008) (intellectual property); Ian Weinstein, Don't Believe Everything You Think: Cognitive Bias in Legal Decision Making, 9 Clinical L. REv. 783 (2003) (reflective lawyering). For criticism of the movement to reassess legal doctrine based on the insights from behavioral economics, see Gregory Mitchell, Why Law and Economics' Perfect Rationality Should Not Be Traded for Behavioral Law and Economics, 91 GEO. L.J. 67 (2002).

103. See infra notes 110-28 and accompanying text. Cass Sunstein has also discussed the existence and role of what he calls "moral heuristics," although he notes the difficulty in their identification and application. See Cass R. Sunstein, Moral Heuristics and Moral Framing, 88 MINN. L. REV. 1556 (2004). 
WorldCom. ${ }^{104}$ This section reviews research on the psychology of conflicts of interest and discusses its application to criminal cases.

\section{A. Psychological Research and Conflicts of Interest}

Researchers have identified limits on the cognitive abilities of people to make rational judgments. The notion, now well-documented, is that human decisions are limited by a host of heuristics, or mental short cuts, that are essential when humans process information. ${ }^{105}$ These shortcuts, while necessary for the speedy mental processing of information, also lead to predictable biases and errors in judgment. Many of the systematic errors that have been identified are relevant to legal decisionmaking. For example, due to what has been called "extremeness aversion," people are adverse to extremes and tend to seek compromise, which explains why the framing of choice is so important to predicting the result that will be achieved in any situation. ${ }^{106}$ Another welldocumented heuristic, "hindsight bias," leads people to overstate the predictability of past events. ${ }^{107}$ This body of research documenting the limits on rationality emanates from the study of what has been labeled "bounded rationality," the central idea of which is that humans are less rational in making decisions than classic economic theory suggests. ${ }^{108}$

104. See Don A. Moore et al., Introduction, in CONFLICTS OF INTEREST 1, 1 (Don Moore et al. eds., 2005). Conflicts of interest have been identified as one of the principal causes of accounting and auditing failures that led the collapse of companies such as Enron and Worldcom. See, e.g., Joel Seligman, No One Can Serve Two Masters: Corporate and Securities Law After Enron, 80 WASH. U. L.Q. 449, 472-77 (2002). The recent economic problems precipitated by the subprime lending crisis have also been associated with conflicts of interest, especially conflicts that existed by the rating agencies responsible for assessing the risk of mortgage-backed securities. See Eric Lipton \& Raymond Hernandez, A Champion of Wall Street Reaps Benefits, N.Y. TIMES, Dec. 14, 2008, at A1.

105. See BeHAVIORAL LAW AND ECONOMICS, supra note 100, at 3; see also HeURISTICS AND Biases: The Psychology of InTUitive Judgment (Thomas Gilovich et al. eds., 2002). For the seminal work documenting and discussing heuristics and biases, see JUDGMENT UNDER UNCERTAINTY: HEURISTICS AND BIASES (Daniel Kahneman et al. eds., 1982).

106. See BehaVioral LAW AND ECONOMiCs, supra note 100, at 3; see, e.g., J.J. Prescott \& Sonja Starr, Improving Criminal Jury Decision Making After the Blakely Revolution, 2006 U. ILL. L. REV. 301, 329-30 (2006) (discussing the implications of extremeness aversion on sentencing options in criminal cases); Cass R. Sunstein, Behavioral Analysis of Law, 64 U. CHI. L. REV. 1175, 1181-82 (1997) (discussing the legal implications of extremeness aversion).

107. See Behavioral LAW AND ECONOMICS, supra note 100, at 4; see, e.g., Jeffrey J. Rachlinski, A Positive Psychological Theory of Judging in Hindsight, in BEHAVIORAL LAW \& ECONOMICS, supra note 100, at 95-115 (discussing various legal implications of hindsight bias). For a discussion of the role of hindsight bias in cases where ineffective assistance of counsel is alleged, see Stephanos Bibas, The Psychology of Hindsight Bias and After-The-Fact Review of Ineffective Assistance of Counsel, 2004 UTAH L. REV. 1 (2004).

108. See BeHAVIORAL LAW AND ECONOMICS, supra note 100, at 14-16 (discussing bounded rationality and its related concepts, bounded willpower and bounded self-interest); see also Chugh et al., supra note 26, at 76-77 (discussing bounded rationality and related concepts); Milton Regan, 
Applying insights from this and related areas of study, researchers are now focusing on biases that occur in ethical judgments, including conflicts of interest. For example, researchers from Harvard University have identified a model of behavior termed "bounded ethicality," which concludes that, similar to the bounded nature of rationality, people are limited during the process of making ethical decisions, such as those involving conflicts of interest. ${ }^{109}$ Relying on psychological research by numerous experts, this model concludes that humans are motivated toward "perceptions, judgments, and behaviors that are biased toward the goal of maintaining self-worth, not just toward the more neutral goals of speed and efficiency" in decision-making. ${ }^{110}$ The key to understanding this model of behavior is that forces favoring self-worth operate at an unconscious level - that is, beyond the scope of rational perception and judgment — as do other documented heuristics.

Three specific biases relating to the motivation to maintain a positive view of the self have been identified as the core of bounded ethicality. ${ }^{111}$ All are unconscious in that they occur below the decision-maker's level of awareness. The first, called the "self as moral" bias, describes the tendency to believe oneself as more "honest, trustworthy, ethical, and fair than others." 112 This bias is also described as the "illusion of objectivity"- people consistently consider themselves more objective than their average peer. ${ }^{113}$ This overconfidence means that humans tend

Moral Intuitions and Organizational Culture, 51 ST. LouIs U. L.J. 941 (2007) (discussing and citing related research).

109. Chugh et al., supra note 25, at 74-103. Max Bazerman of Harvard Business School, who has been responsible for much of the research on bounded ethicality, provides a comprehensive literature review in this area at http://www.people.hbs.edu/mbazerman/bounded_ethicality.htm. For an excellent discussion of bounded ethicality and related research as applied to corporate directors, see Anthony Page, Unconscious Bias and the Limits of Director Independence, 2009 U. ILL. L. ReV. 237.

110. Chugh et al., supra note 25 , at 78 . Research applying bounded ethicality to particular circumstances has found, for example, that implicit stereotyping is not the product of rationality, but rather the result of automatic processes that occur below conscious awareness. Id. at 79 (citing Mahzarin R. Banaji \& R. Bhaskar, Implicit Stereotypes and Memory: The Bounded Rationality of Social Beliefs, in Memory, Brain \& Belief 139-75 (Daniel L. Schacter \& Elaine Scarry eds., 2000)). Research in this area includes the creation of Project Implicit, a collaborative virtual enterprise between numerous research universities into "implicit social cognition." Project Implicit, http://www.projectimplicit.net/about.php (last visited Aug. 25, 2009). As described on the project's website, implicit social cognition includes the "cognitions, feelings, and evaluations that are not necessarily available to conscious awareness, conscious control, conscious intention, or selfreflection." Id.

111. See Chugh et al., supra note 25, at 81 .

112. Id.

113. Id. (citing research from five studies in which eighty-five percent of participants rated their own objectivity higher than that of their peers). Examples of the illusion of objectivity abound. For example, in one study people were assigned responsibility for deciding the wages for work 
to justify questionable ethical behavior as a self-defense to maintain their illusions. ${ }^{114}$ The second, called the "self as competent" bias, describes the false perception people have of themselves as being better than others in possessing a series of desirable attributes. ${ }^{115}$ These include traits such as "cooperativeness, decision making, negotiating, rationality ... and intelligence." "Th The third bias, "self as deserving," means that people allocate more responsibility to themselves for contributions to an outcome than they actually deserve. ${ }^{117}$ Each of these biases is "stubborn" in that the decision-maker, not aware of its existence, will tend to believe that he or she acted ethically, even in the face of evidence to the contrary. ${ }^{118}$ Further, evidence of unethical behavior is constantly rearranged by one's sub-conscious to preserve one's self-perceptions as moral, competent and deserving. ${ }^{119}$

These three biases have a significant impact on decision-making in situations where conflicts of interest are present. For example, people's overconfidence in their objectivity tends to make them believe that they

performed. David M. Messick \& Keith Sentis, Fairness, Preference, \& Fairness Biases, in EQUITY Theory: Psychological and Sociological Perspectives 61, 63-64 (David M. Messick \& Karen S. Cook eds., 1983). Believing they were making a fair allocation, study participants determined that they deserved, on average, $\$ 35.24$ for ten hours of work, but concluded that their partner deserved only $\$ 30.29$ for the same work. Id. at 70 . Similarly, participants in a study to determine the effects of self-serving biases in a legal dispute were randomly assigned to the role of either plaintiff or defendant in a hypothetical case. George Lowenstein et al., Self-Serving Assessments of Fairness and Pretrial Bargaining, 22 J. Legal Stud. 135, 139 (1993). The participants differed in their perceptions of a fair settlement by nearly $\$ 18,000$ in the direction that served the side to which they were assigned. Id. at 150. For a discussion of these and other studies, see Nicholas Epley \& Eugene M. Caruso, Egocentric Ethics, 17 SoC. JusT. RES. 171-87 (2004).

114. Chugh et al., supra note 25 , at $82-83$.

115. Id. at 84 .

116. Id.

117. Id. at $85-86$. One area extensively studied is the degree to which people believe that they have control over chance events. For an excellent discussion, see Shelley E. Taylor \& Jonathan D. Brown, Illusion and Well-Being: A Social Psychological Perspective on Mental Health, 103 PSYCHOL. BULL. 193, 196 (1988) ("In a series of studies adopting gambling formats, [researchers] found that people often act as if they have control in situations that are actually determined by chance. When manipulations suggestive of skill, such as competition, choice, familiarity, and involvement, are introduced into chance situations, people behave as if the situations were determined by skill and, thus, were ones over which they could exert some control. For example, people infer that they have greater control if they personally throw dice than if someone else throws it for them. Similarly, a large literature on covariation estimation indicates that people substantially overestimate their degree of control over heavily chance-determined events. When people expect to produce a certain outcome and the outcome then occurs, they often overestimate the degree to which they were instrumental in bringing it about.") (citations omitted).

118. Chugh et. al., supra note 25 , at 80 .

119. Id. This tendency has been described as the "totalitarian ego," where the ego "tampers and rearranges self-knowledge so as to ensure that a certain view is maintained, but retains no conscious belief that such tampering has taken place." Id. (citing A.G. Greenwald, The Totalitarian Ego: Fabrication and Revision of Personal History, 35 AM. Psychol. 603 (1980)). See also Epley \& Caruso, supra note 113. 
will not be influenced by divergent interests at stake. ${ }^{120}$ In addition, when one engages in questionable ethical behavior, one's automatic process of self-defense, born out of the motivation to see one's self as moral, justifies the behavior as being consistent with ethical norms. ${ }^{121}$ The biases of the self as competent and deserving help justify questionable conduct, allowing one to believe that decisions that enhance self-interest comport with ethical norms. ${ }^{122}$

The role of self-interest is essential to understanding the limits of rational deliberation when conflicts of interest are present. Researchers from Carnegie Mellon University have focused on the "automaticity" of thought in explaining this behavior. ${ }^{123}$ According to the research, conflicts of interest are an example of the "dual process model" of decision-making, in which the human mind processes self-interest "automatically," while decisions about professional responsibility are processed by the "controlled" mode of analytical thought. ${ }^{124}$ While automatic processing occurs outside of conscious awareness, and thus cannot be voluntarily curtailed, controlled processing is the product of deliberation, which is subject to volition and control. ${ }^{125}$

In most instances, automatic and controlled processes work together to make decisions. But when a conflict of interest is present, and selfinterest and professional responsibility collide, the decision often results

120. Chugh et al., supra note 25, at 82-83. For example, in 2000, the CEO of Arthur Anderson testified before the Securities and Exchange Commission that then-existing standards of professionalism and objectivity in the accounting industry were sufficient to ensure auditor independence, notwithstanding the possibility of conflicts of interest. Id. We now know that these standards were far from sufficient to prevent the accounting scandals that led to the collapse of firms such as Arthur Anderson. For a discussion of how unconscious biases produced conflicts of interests that were at the root of these accounting scandals, see Don A. Moore et al., Conflicts of Interest and the Case of Auditor Independence: Moral Seduction and Strategic Issue Cycling, 31 ACAD. MGMT REV. 10 (2006) [hereinafter Moral Seduction].

121. See Chugh et al., supra note 25 , at 83.

122. Id. at 84-86. The bounded nature of ethical decision-making is particularly prevalent when self-evaluation is difficult to disprove. $I d$. at 82 . According to the research, when no objective measure of ethicality is present, the ability to aggrandize the self at the expense of others is enhanced. Id. In the face of ambiguity, the illusion of objectivity undermines the ability to identify conflicts of interest that are present. Id. For discussion of the ambiguity in the ethical rules governing conflicts of interest in law, see infra notes 145-46 and accompanying text.

123. Moore \& Lowenstein, supra note 25, at 189-202.

124. Id. at $190-92$.

125. Id. A classic example of automatic processing is vision, an activity that involves "numerous parallel processes-e.g., edge and pattern recognition and retrieval of information from memory." Id. at 191. Some characteristics of vision, which are typically true of all automatic processes, are that it is largely unaccompanied by any feeling of subjective effort and is involuntary. Id. In addition, the "cognitive processes that give rise to vision are almost totally inscrutable," meaning that most people would be unable to explain the brain activity that correlates to why humans see whatever is in their field of vision. Id. 
in an automatic preference for self-interest. ${ }^{126}$ This results in a critical observation: while the decision-maker will believe that the decision comes from rational deliberation where all competing concerns are considered and weighed, in actuality the automatic bias toward selfinterest will often create an error in judgment that favors self-interest, "automatically and without conscious awareness." 127 In other words, the decision-maker will rationalize behavior as consistent with ethical norms, even when in actuality the decision preferences self-interest.

This process of ethical rationalization has been identified and discussed by other researchers. For example, Jonathan Haidt, a Professor of Psychology at the University of Virginia, has proposed a "social intuitionist model" to explain the specific processes by which ethical rationalization occurs. ${ }^{128}$ According to Haidt, whose work relies on an exhaustive survey of existing social science literature, most moral judgments are not the product of rational deliberation, as often believed. ${ }^{129}$ Rather, the precipitating cause is "moral intuition," which is defined as "the sudden appearance in consciousness of moral judgment" that occurs "without any conscious awareness of having gone through steps of searching, weighing evidence, or inferring a conclusion." 130 As with other automatic processes, intuition appears effortlessly and

126. Id. at 194-96.

127. Id. at 199. The power of automatic processes is explained by a number of factors, including the speed with which automatic processes operate, the powerful influence that affect has on how information is retrieved from memory, and the additional cognitive scrutiny that information inconsistent with automatic processes tends to receive. Id. at 193.

128. Jonathan Haidt, The Emotional Dog and Its Rational Tail: A Social Intuitionist Approach to Moral Judgment, 108 PsYchol. ReV. 814, 814 (2001) [hereinafter The Emotional Dog]. For other descriptions of the social intuitionist model, including responses to critics, see Jonathan Haidt, The Emotional Dog Gets Mistaken for a Possum, 8 REV. GEN. PsyCHOL. 283 (2004); Jonathan Haidt \& Craig Joseph, Intuitive Ethics: How Innately Prepared Intuitions Generate Culturally Variable Virtues, 133 DAEDALUS 55 (2004). Haidt's work is cited by both the Harvard and Carnegie Mellon research teams. See Chugh et al., supra note 25, at 83; Moore \& Lowenstein, supra note 25, at 194.

129. See The Emotional Dog, supra note 128, at 816-17 (questioning the causality of moral reasoning). According to Haidt, the primary proponent of the rationalist approach to moral judgments was Lawrence Kohlberg, who argued in favor of a six-level progression of human development. Id. at 816. Kohlberg's research has been the basis for discussions about professionalism and legal ethics. See, e.g., Steven Hartwell, Promoting Moral Development Through Experiential Teaching, 1 CLINICAL L. REV. 505 (1995) (discussing Kohlberg's theory of moral development in teaching Professional Responsibility).

130. The Emotional Dog, supra note 128, at 818. In setting forth his model, Haidt relies on research demonstrating that most judgments, including moral judgments, are made through the types of automatic, as opposed to controlled, processes of thought just described. Id. at 819-20; supra notes 123-27 and accompanying text. Others have also described the importance of intuition in legal decision-making. See, e.g., Paul H. Robinson \& John R. Darley, Intuitions of Justice: Implications for Criminal Law and Justice Policy, 81 S. CAL. L. REV. 1, 3 (2007) (discussing intuition in the context of criminal policy). 
unconsciously. ${ }^{131}$ In contrast, "moral reasoning"-which is the intentional, conscious and effortful process of making an ethical judgment, such as the conscious effort to consider ethical norms - is the "slow, ex post facto process" that tends to explain, or rationalize, the decision already made. ${ }^{132}$ In other words, the decision-maker uses rational thought to "search for arguments that support an already-made judgment" through moral intuition. ${ }^{133}$ Using an analogy, Haidt explains that the dog of moral intuition wags the tail of moral reasoning. ${ }^{134}$

Applying Haidt's work to conflicts of interest helps to explain the decision-making process at work. Most decision-makers believe that the decisions they reach are the result of careful evaluation of existing norms, when in fact such post hoc reasoning functions merely to explain decisions previously reached through moral intuition. ${ }^{135}$ Further, post hoc explanations are motivated by the same biases that favor self-interest in judgment, as previously described. ${ }^{136}$ The net result is that, when explaining a moral judgment, people act like "intuitive lawyers"unconsciously focusing on evidence that supports a preordained conclusion and discounting evidence that does not fit. Of course, this is not to say that conscious moral reasoning can never override an initial moral intuition, taking precedence in the causal chain of events. But, according to Haidt, such situations are rare, occurring only when moral

131. See The Emotional Dog, supra note 128, at 818. Haidt describes four links in his social intuitionist model: (1) The intuitive judgment link, which involves the effortless and automatic awareness in consciousness of a moral judgment; (2) the post hoc reasoning link, which involves the effortful process whereby the decision-maker "searches for arguments that will support an alreadymade judgment"; (3) the reasoned persuasion link, which involves the verbalization of the moral judgment, which can influence the moral intuitions of others; and (4) the social persuasion link, which describes the dominant influence of group norms on moral reasoning. $I d$. at 818-19. According to the model, moral reasoning has a role in ethical decision-making, which occurs by way of two additional links: (1) the reasoned judgment link, which describes the rare situations in which people can override an initial moral intuition by the "sheer force of logic," and (2) the private reflection link, which describes how a person can spontaneously activate an intuition that opposes initial moral intuitions. Id. at 819. Role-taking, where a person views a situation from the perspective other than one's own, can result in activating the private reflection link. Id. For a description and application of Haidt's model, see Regan, supra note 108 (applying the social intuitionist model in assessing moral decision-making in organizational settings).

132. The Emotional Dog, supra note 128, at 814. In coming to this conclusion, Haidt relies on research studies on "post hoc constructions," which describes situations where people who are asked to explain their behavior believe that they are engaging in introspection to discover its cause, but in fact are searching for "plausible theories about why they might have done what they did." Id. at 822 23 (citing Richard E. Nisbitt \& Timothy DeCamp Wilson, Telling More Than We Know: Verbal Reports on Mental Processes, 84 Psychol. ReV. 231, 248 (1977)).

133. The Emotional Dog, supra note 128 , at 818 .

134. Id. at 825 .

135. The processes by which intuitions are formed are complex, and depend in large measure on a culture's collective sense of right and wrong, good and bad. Id. at 827-28.

136. See supra notes 110-28 and accompanying text. 
intuition is weak and the capacity of the decision-maker to engage in reasoned judgment is strong. ${ }^{137}$

A slightly different explanation of ethical rationalization focuses on what has been described as the "temporal trichotomy of prediction, action and recollection" of ethical judgments. ${ }^{138}$ Studies demonstrate that people tend to overestimate their ability to act ethically, both prospectively when asked to consider how ethical they will be in the future and in hindsight when asked to evaluate how ethical they have been in the past. ${ }^{139}$ The cause of these erroneous judgments is the motivations present at different moments in time. When looking prospectively, people tend to focus on what "should" happen. ${ }^{140}$ In contrast, during the phase when action itself takes place, what people "want" tends to dominate. ${ }^{141}$ Looking backward, people tend to erroneously identify conduct that should have dominated the decisionmaking process, when in fact it was people's wants that dominated behavior. ${ }^{142}$

In sum, research demonstrates that, just as cognitive heuristics and biases systematically cause deviations from full rationality, so too a set of motivations causes systematic deviations from full ethicality and professional responsibility when conflicts of interest are present. Professionals often believe falsely that they will not be corrupted by conflicts of interest, yet in reality they are subject to the same unconscious biases toward self-interest and self-worth as everyone

137. The Emotional Dog, supra note 128, at 819. See also Jonathan Haidt \& Fredrik Bjorklund, Social Intuitionists Answer Six Questions About Morality, in 2 Moral Psychology: THE COGNitive SCIENCE OF MORALITY 181 (Walter Sinnott-Armstrong ed., 2008).

138. Ann Tenbrunsel et al., Why We Aren't as Ethical as We Think We Are: A Temporal Explanation 3 (Harvard Bus. Sch., Working Paper No. 08-012, 2007), available at http://hbswk .hbs.edu/item/5763.html.

139. Id. at $13-16,24-30$

140. Id. at 4 .

141. Id.

142. Id. at 24-30. The research reveals a series of factors that make the "want-self" dominant during the "action phase," that is, at the moment when the decision with ethical implications is made. Id. at 25-26. First, people's forecasts of future ethicality tend to be abstract and do not include the many factors that will be present when a decision is actually made. $I d$. at $16-17$. For example, in predicting one's future willingness to make a charitable contribution, one fails to perceive many of the factors - such as constraints, distractions, and more immediate needs - that may be present at the moment of decision. Id. at 17-18. Second, research demonstrates that various factors can diminish the degree to which people become aware of a particular decision's ethical dimension. Id. The result, described as "moral fading," has been demonstrated to occur, for example, when a weak sanction is in place, when the decision-maker is overly focused on meeting a standard rather than satisfying an ethical goal, or when linguistic disguises cover up unethical aspects of a decision. Id. at 20-22. Third, visceral factors present at the moment of decision (such as mood, pain, and hunger) can crowd out other goals, such as a focus on the wants and needs of others. Id. at 23-24. 
else. ${ }^{143}$ The results are errors in judgment, both in predicting whether conflicting interests will have an influence on decisions and when reflecting upon whether a conflict influenced decisions previously made. Like all cognitive biases, these errors occur below the level of consciousness, invisibly infecting the decision-making process but leaving no trail.

\section{B. Psychological Biases in Criminal Cases}

A number of issues arise about the applicability of the psychology of conflicts of interest in criminal cases. The first is whether social science research applies to lawyers in general, whose conduct is constrained by rules of professional responsibility. In other words, can the selfregulation of lawyers act as a check on self-interest when conflicts are present?

The answer, unfortunately, is that the rules alone do not provide sufficient safeguards. As already discussed, the rules governing conflicts of interest provide lawyers with substantial latitude to decide whether representation is permitted. ${ }^{144}$ Indeed, except for a few situations, lawyers must decide both the risk of divided loyalties and whether waiver is both permitted and appropriate. ${ }^{145}$ Research demonstrates that situations where discretion is permitted, and bright lines do not exist, are where psychological biases that skew judgment are most likely to operate. $^{146}$ Given these circumstances, there is little reason to believe that the governing rules will be able to check the unconscious pull of self-interest.

Leonard Gross, who has evaluated the conflicts provisions of the Model Rules, has come to the same conclusion. Looking at the issue through the prism of behavioral economics, his work relies on research

143. See Chugh et al., supra note 25, at 90-91; see also Gross, supra note 23, at 113 (noting that "social science literature suggests that a lawyer will rationalize his behavior as being ethical because of the innate human tendency to rationalize one's self-interest as being consistent with morality") (citing Susan Daicoff, (Oxymoron?) Ethical Decisionmaking by Attorneys: An Empirical Study, 48 FLA. L. REV. 197, 238 (1996))).

144. See supra notes 41-55 and accompanying text; see also Zacharias, supra note 38, at 436 (discussing the ambiguity of the Model Rules that cover conflicts of interest).

145. Only a few of the rules governing conflicts of interest create bright line rules prohibiting certain types of conduct. See, e.g., MODEL RULES OF PROF'L CONDUCT R. 1.8(d) (2008) (prohibiting agreements giving lawyers literary or media rights during representation); Id. R. 1.8(e) (prohibiting provision of financial assistance to clients during litigation); Id. R. 1.8(j) (prohibiting sexual relations between lawyers and clients during representation).

146. See Chugh et al., supra note 25, at 82; Gross, supra note 23, at 115-16. 
into heuristics and related fields, ${ }^{147}$ similar to the body of research that the Harvard and Carnegie Mellon teams rely upon in analyzing the psychology of conflicts. After reviewing available research and conducting his own study, ${ }^{148}$ Gross has concluded that the rules of professional responsibility do not check unconscious biases that cause lawyers to act out of self-interest when conflicts of interest are present. ${ }^{149}$

Research on other professions is consistent with this conclusion. For example, a series of studies on accountants reveals that psychological biases produce conflicts of interest, notwithstanding rules that are supposed to check self-interest. ${ }^{150}$ Similarly, doctors have been found to suffer from psychological biases that make it difficult to check conflicts of interest caused by gifts and other incentives from outside groups, such as the pharmaceutical industry. ${ }^{151}$ Similar findings have been made about researchers in various areas of public policy. ${ }^{152}$

147. See Gross, supra note 23, at 115-25. Gross surveys many of the cognitive heuristics that can come into play when a lawyer makes a decision about conflicts of interest. Id. They include the "availability" heuristic (the bias in favor of circumstances that most readily come to mind); the "optimism" bias (the tendency to be overly optimistic that bad things will not happen); "ambiguity aversion" (the tendency to prefer known to unknown risks); "prospect theory" (the tendency to be more risk adverse when locking in a gain, and risk-seeking when choosing between losses); and the "endowment effect" (the tendency to place greater value on what is owned than on what is not). See $i d$. at 116-20. For discussion of these and many other heuristics that have been identified through research, see JUDGMENT UNDER UNCERTAINTY: HEURISTICS AND BIASES, supra note 105.

148. Gross, supra note 23, at 127. The study sent surveys to 439 graduates of Southern Illinois University School of Law, 157 of whom responded. Id. The data indicated that few lawyers discuss conflicts of interest with their clients on a frequent basis. Id. at 128. However, when lawyers do identify conflicts, they "overwhelmingly indicate that they believe that the conflicts are waivable." $I d$. The study concluded that, while it is possible that lawyers rarely have conflicts of interest, the "more plausible explanation" is that lawyers "do not reveal many conflicts to their clients" because of "self-interest." Id. at 130 .

149. Id. at 125-33.

150. See, e.g., Moral Seduction, supra note 120, at 10 (stating that "[a]ccounting firms have incentives to avoid providing negative audit opinions to the managers who hire them and pay their auditing fees"); Max H. Bazerman et al., Reports of Solving the Conflicts of Interest in Auditing Are Highly Exaggerated, 31 ACAD. OF MGMT. REV. 43 (2006) (stating that accountants' "motivation to please their clients represented a conflict of interest threatening both their reputations and their objectivity"); see also Chugh et al., supra note 25, at 88-89 (citing studies demonstrating that professional auditors are "vulnerable to the same motivated biases as are other people").

151. See, e.g., Jerome P. Kassirer, Physicians' Financial Ties with the Pharmaceutical Industry, in CONFLICTS OF INTEREST, supra note 25, at 133-41 (discussing the close relationships between doctors and the pharmaceutical industry); Andrew Stark, Why Are (Some) Conflicts of Interest in Medicine So Uniquely Vexing?, in CONFLICTS OF INTEREST, supra note 25, at 152-80 (discussing pharmaceutical company gifts of equipment and travel to physicians that blur internal and external interest for the physicians); Jason Dana \& George Lowenstein, A Social Science Perspective on Gifts to Physicians from Industry, 290 J. AM. MED. Ass'N 252-55 (2003) (stating "physicians typically report that they are not biased by financial arrangements with pharmaceutical companies, although a large body of research suggests that they are").

152. See, e.g., Robert J. MacCoun, Conflicts of Interest in Public Policy Research, in ConfLICTS OF INTEREST, supra note 25, at 233-62 (discussing the varieties of conflicts of interest public policy 
A second issue that arises is whether, even if psychological research applies to lawyers in general, does it apply to the types of conflicts that arise in criminal cases? As previously noted, many conflicts in criminal cases seem, at least on the surface, to be between duties that lawyers owe to others, rather than between the self-interest of the lawyer and duties of professional responsibility. ${ }^{153}$ Under these circumstances, does research that focuses on self-interest apply?

To be sure, some situations present a direct conflict between a lawyer's self-interest and duties to others, such as those identified in Model Rule 1.8. ${ }^{154}$ But many other cases seem, at least at first glance, to involve situations where self-interest is not as apparent. For example, multiple representation would seem to raise conflicts only between the obligations to two or more clients, not between the interests of the lawyer and clients. Similarly, successive representation seems to raise conflicts only between a current and former client, not between the lawyer and clients. In these situations, where the lawyer is balancing competing obligations to others, are the unconscious biases that produce errors in judgment present?

A closer look at conflicts in criminal cases reveals that lawyer selfinterest lurks below the surface in many situations. For example, when a privately retained lawyer is required by the ethical rules to withdraw from, or to forgo, representation because of a conflict, there is a direct economic impact in the loss of a paying client. As a result, the decision on whether a conflict exists or is waivable is connected directly to the lawyer's self-interest. ${ }^{155}$ These same interests exist for lawyers paid from public funds on a per case basis to represent indigent defendantsthe loss of one client due to a conflict will have an economic impact on the lawyer's earnings. ${ }^{156}$

researchers face).

153. See supra notes $28-38$ and accompanying text.

154. MOdEL RULES OF PROF’L CONDUCT R. 1.8 (2008) (listing personal conflicts regulated by this rule).

155. See sources cited supra note 65 (discussing the economic interests at stake).

156. Indigent defense services in the United States are funded in three principal ways: (1) the public defender model, whereby through either a public agency or private organization attorneys are paid as salaried employees; (2) the assigned counsel model, where private attorneys receive court appointments and are paid either on an hourly basis or a flat fee per case; and (3) the contract model, whereby an organization of attorneys agrees to handle a set number of cases, paid either per case or on a flat fee. The Spangenberg Group, Rates of COMPENSATION PAID to COURT-APPOINTED COUNSEl IN NON-CAPital Felony CaSes at TRial: A State-By-State Overview 1-2 (2003) www.abanet.org/legalservices/downloads/sclaid/indigentdefense/compensationratesnoncapital 2003. pdf. Criticism levied against the inadequacy of funding for indigent defense services has been plentiful. E.g., Standing Committee on Legal Aid AND Indigent Defendants, Am. BAR Ass'N, GIDEON's BROKEn PROMISE: AMERICA's CONTINUING QueST FOR EQUAL Justice 7-37 
But what of the many public defenders who are not paid per case? ${ }^{157}$ For them, self-interest also exists below the surface, but can cut in different ways depending upon the situation. Some cases might be sufficiently glamorous that a public defender would want to stay on the matter because of the media exposure it promises: the publicity might benefit the lawyer's future earning prospects or reputation. Alternatively, a lawyer who has invested substantial effort on behalf of a defendant may have an interest in seeing the case to its conclusion, even when there is no economic incentive in doing so.

In contrast, when a case has no media value, and no other interests favor keeping the case, the incentives might pull in the opposite direction. Public defenders maintain notoriously excessive caseloads that make the provision of quality representation difficult. ${ }^{158}$ The corresponding incentive, therefore, is to reduce caseloads whenever possible since fewer cases means fewer hours of work for the already overworked public defender. Conflicts give the defender a ready excuse either to decline an appointment of representation, or to withdraw from an appointment already made.

In cases where a defense lawyer has been accused of ineffective assistance of counsel and is called upon to testify about decisions made during representation, self-interest becomes more obvious. In such circumstances, there is a direct clash between duty and self-interest. Like all witnesses, a lawyer has a duty to be forthright and candid while testifying. Yet, at the same time, a finding that the lawyer has been ineffective can cause the lawyer damage, including casting a shadow on the lawyer's reputation, ${ }^{159}$ undermining the lawyer's future earning

(2004) [hereinafter GIDEON'S BROKEN PROMISE], www.abanet.org/legalservices/sclaid/ defender/brokenpromise/fullreport.pdf; Norman Lefstein, In Search of Gideon's Promise: Lessons from England and the Need for Federal Help, 55 HASTINGS L.J. 835, 844 (2004).

157. For example, the salary paid to lawyers under the public defender model does not depend on the number of clients served. See The SPANGENBERG Group, supra note 156, at 1-2 (stating that the public defender model utilizes employees who are paid a salary).

158. See GIDEON'S BROKEN PROMISE, supra note 156, at 17 (describing examples of crushing caseloads); Erica J. Hashimoto, The Price of Misdemeanor Representation, 49 WM. \& MARY L. REV. 461, 464 (2007) ("Outrageously excessive caseloads have compromised the quality of indigent defense representation.").

159. See Bruce A. Green, Criminal Neglect: Indigent Defense from a Legal Ethics Perspective, 52 EMORY L.J. 1169, 1186 (2003) (noting that a finding of ineffectiveness would impose a cost on the reputation of defense counsel); Siegel, supra note 90, at 86-87 (discussing the conflict between a lawyer's duties as a witness and a lawyer's own self-interest). Others have noted that reputation may be a lawyer's most valuable asset, the protection of which will be a lawyer's highest priority. See Darryl K. Brown, Criminal Procedure Entitlements, Professionalism, and Lawyering Norms, 61 OHIO ST. L.J. 801, 822 n.96 (2000); Judith A. McMorrow et al., Judicial Attitudes Toward Confronting Attorney Misconduct: A View from the Reported Decisions, 32 HofsTRA L. REV. 1425, 1428 n.15 (2004). 
potential, and exposing the lawyer to possible professional discipline or a claim for legal malpractice. ${ }^{160}$ The result of these incentives on the intentional conduct of lawyers is hard to know. Some suggest that, as a result of potential harms, lawyers accused of ineffectiveness will not cooperate in post-conviction proceedings, and may even go so far as to distort the truth to avoid the various harms of being found ineffective. ${ }^{161}$ Indeed, some of these very concerns were raised in Mickens about Bryan Saunders, whose pecuniary and reputational interests created an incentive for false testimony. ${ }^{162}$ At the unconscious level, however, the research on psychology of conflicts indicates that, because of the potential harms that can befall an attorney found to be ineffective, defense lawyers will be subject to the types of unconscious biases that favor self-interest in post-conviction proceedings.

In sum, the tensions between self-interest and professional obligation identified in the research on conflicts of interest will exist to varying degrees. While some lawyers will be able to act consistent with their clients' interests, many others will be unable to make accurate assessments when deciding whether a conflict of interest is present. In

160. The connections between a finding of ineffectiveness and other harms to a lawyer's interests have been noted elsewhere. See, e.g., Burger v. Kemp, 483 U.S. 776, 806 n.11 (1987) (Blackmun, J., dissenting) (noting that the attorney accused of ineffectiveness in that case "is not a fully disinterested party to this proceeding due to the collateral consequences that could result from a determination that he rendered ineffective assistance of counsel. He certainly has an interest in disavowing any conflict of interest so that he may receive other court appointments that are a source of clients for the criminal defense work of the partners' practice."). For example, a finding that a defense lawyer rendered effective assistance of counsel will, in most jurisdictions, collaterally estop a claim for professional malpractice, thus creating an incentive for lawyers to oppose ineffectiveness claims. See Koniak, supra note 90, at 7; Ann M. Voigts, Narrowing the Eye of the Needle: Procedural Default, Habeas Reform, and Claims of Ineffective Assistance of Counsel, 99 CoLuM. L. REV. 1103, 1126 (1999). The converse is not true: a finding of ineffectiveness will not, by itself, be sufficient to establish malpractice. Rather, in many jurisdictions, a defendant will need to establish actual innocence as a prerequisite to a malpractice claim. See Meredith J. Duncan, The (So-Called) Liability of Criminal Defense Attorneys: A System in Need of Reform, 2002 BYU L. REV. 1, 37-38 (2002).

161. See, e.g., Koniak, supra note 90, at 7; Voigts, supra note 160, at 1126; Lowenthal, supra note 33, at 28; see also Massaro v. United States, 538 U.S. 500, 506 (2003) (“Appellate counsel often need trial counsel's assistance in becoming familiar with a lengthy record on a short deadline, but trial counsel will be unwilling to help appellate counsel familiarize himself with a record for the purpose of understanding how it reflects trial counsel's own incompetence."); Cf. Kyle Graham, Tactical Ineffective Assistance in Capital Trials, 57 AM. U. L. REV. 1645, 1646-48 (2008) (noting that defense attorneys can "sandbag" the final verdict by intentionally engaging in ineffective assistance of counsel).

162. See Brief for Petitioner, supra note 5, at *33 (noting the difficulty of post hoc assessments of "adverse effect," which is likely to prove to be a "futile attempt to pin down a scared, selfprotective, slippery lawyer, anxious to escape ethical censure at whatever cost to a former client"); see also Brief of Legal Ethicists, supra note 21, at*14-15 (arguing that Saunders's silence about his prior representation of the victim was motivated by pecuniary and reputational interests and "defies a benign explanation"). 
addition, all will find it difficult in hindsight to provide an accurate assessment about whether a conflict had an adverse effect on the representation provided to a client. Under these circumstances, Part IV addresses whether and how current doctrine should be modified to take into account these psychological realities.

\section{IMPLICATIONS FOR EXISTING DOCTRINE}

The many ways that self-interest can unconsciously influence the judgment of defense lawyers requires a fresh look at existing doctrine. Given the empirical research on conflicts of interest, what is the best way to protect defendants from conflicts while, at the same time, protecting the other interests at stake in criminal proceedings? Options include mandating greater disclosure in conflicts cases, limiting the discretion of trial courts to grant disqualification motions, prohibiting certain types of representation altogether, and changing the burden of proof that defendants must meet when a conflict of interest is alleged. Each of these options is discussed below.

\section{A. Disclosure Requirements}

One option is to require more disclosure about the risks involved when circumstances suggest that a conflict of interest exists or is likely. This option hypothesizes that a defendant who better understands the risks would be better able to decide how to proceed, either by objecting to the appointment of an attorney who is paid by public funds or, in the case of a private retainer, by hiring new counsel. The form and circumstances under which disclosure is mandated could vary. For example, warnings similar to those mandated by federal law in cases of multiple representation ${ }^{163}$ could be required in every case. Alternatively, a rule could be created requiring trial courts to provide warnings to defendants only when, in the court's estimation, there is sufficient risk of a conflict. Devising an appropriate rule of disclosure might be a common sense and relatively non-intrusive way of addressing conflicts of interest. ${ }^{164}$

163. See supra text of note 29 .

164. See Daylian M. Cain et al., Coming Clean but Playing Dirtier: The Shortcomings of Disclosure as a Solution to Conflicts of Interest [hereinafter Cain, Coming Clean but Playing Dirtier], in CONFLICTS OF InTEREST, supra note 25, at 107; Daylian M. Cain et al., The Dirt on Coming Clean: Perverse Effects of Disclosing Conflicts of Interest [hereinafter Cain, The Dirt on Coming Clean], 34 J. Legal STUD. 1, 3 (2005). For example, many of the regulatory reforms in the Sarbanes-Oxley Act of 2002, which were crafted in response to the corporate scandals associated 
The problem with disclosure, it turns out, is that conflicts of interest are not easily remedied by providing decision-makers with more and better information. According to available research, a series of cognitive biases make it difficult for disclosure to counteract the effects of conflicting interests. ${ }^{165}$ Simply put, people tend to rely on biased advice even when they should know better. ${ }^{166}$

Three explanations have been offered. First, information that is provided at the beginning of the judgmental process has a powerful influence on the end result, even when one knows that it comes from a biased source. ${ }^{167}$ This "anchoring effect," as it is known, suggests that a defendant will have a hard time discounting biased advice from a lawyer even if the defendant subsequently learns that the lawyer might have a conflict of interest. Of course, in some cases, warnings can be provided prior to the appointment of counsel, for example, during the arraignment of the defendant, which might reduce this bias. But in many other situations - such as where the attorney-client relationship develops prior to the first court appearance or where the reasons to suspect a conflict arise only after the lawyer has been working on the case-the anchoring effect will counteract warnings issued by the court.

Second, people tend to have a hard time unlearning information, even when they know that the information is incorrect. ${ }^{168}$ Known as the "failure of evidentiary discreditation," this tendency makes it difficult to disregard advice from a biased advisor, even when the decision-maker knows that the information is coming from a biased source. This suggests that, even for warnings provided when counsel is appointed, subsequent advice from the lawyer will be hard for the defendant to discount.

Third, because people tend to assume that others will act consistent with their true nature, known as "correspondence bias," they have a hard

with conflicts of interests, focused on mandating greater disclosure to shareholders and investors. See Cain, Coming Clean but Playing Dirtier, supra, at 106; see also Page, supra note 109, at 292 n.404 (discussing Sarbanes-Oxley Act of 2002, §§ 406(a), 407(a), 15 U.S.C. $\S \S 7264(a), 7665$ (a) (2006), which requires "a company to disclose whether it has a code of ethics and a financial expert on its audit committee rather than requiring these actions").

165. See Cain, Coming Clean but Playing Dirtier, supra note 164, at 105.

166. Id. at 114 .

167. Id. at $110-11$. For example, in one study participants were asked to estimate the population of the United States, but before answering were told a number that was either 50 percent higher or 50 percent lower than the correct answer. $I d$. at 111 . Even though participants were informed that the information may have been offered to influence their estimates, they were nonetheless drawn to the suggested anchor: those who heard the higher number made significantly higher estimates than those who heard the lower number. Id. at 111-12; see also Cain, The Dirt on Coming Clean, supra note 164 , at 6 .

168. See Cain, Coming Clean but Playing Dirtier, supra note 164, at 112-13. 
time discounting advice from someone who is in a trusted position. ${ }^{169}$ As a result, a defendant might have a hard time discounting advice from a lawyer who has been appointed to represent his or her interests, even when the defendant knows that a conflict of interest is possible.

The problem does not end there, however. Research also demonstrates that, far from helping to reduce the dangers caused by conflicting interests, disclosure might actually make matters worse. ${ }^{170}$ Again, unconscious biases are to blame. In some situations, advisors may "compensate" unconsciously for the effects of disclosure "by further skewing their advice" to a client. ${ }^{171}$ Similarly, once bias is disclosed, the decision-maker might unconsciously feel that the advisor has been ethical and thus is deserving of more, rather than less, trust. ${ }^{172}$ Finally, disclosure may result in what has been called "moral licensing," which makes the advisor believe that, because the risks have been disclosed, there is less reason to "toe the ethical line and look out for the interests of those receiving their advice." 173

Applying this research to criminal cases suggests that mandating greater disclosure may have little effect on the quality of decisionmaking by defendants. Indeed, it might even cause some lawyers to push harder for waivers of conflicts while, at the same time, making defendants more, rather than less, willing to grant them. ${ }^{174}$ Although disclosure in some cases might be beneficial, ${ }^{175}$ mandating greater disclosure does not seem to be the best avenue for resolving the complications that arise in conflicts cases.

169. Id. at 114 .

170. Id. at 114-16. See also Dana \& Loewenstein, supra note 151, at 252, 254 (describing a study where disclosure had the "perverse effects" of making matters worse, not better); M.P. Dunleavey, Disclosing Bias Doesn't Cancel Its Effects, N.Y. TIMES, July 28, 2007, at C6 (discussing same study).

171. Cain, Coming Clean but Playing Dirtier, supra note 164, at 115; see Cain, The Dirt on Coming Clean, supra note 164, at 7.

172. Cain, The Dirt on Coming Clean, supra note 164, at 6 (citing Fiona Lee et al., Mea Culpa: Predicting Stock Prices from Organizational Attributions, 30 PersonAlity AND Soc. PsychOL. BULL. 1636-49 (2004)).

173. See Cain, The Dirt on Coming Clean, supra note 164, at 6.

174. This research provides at least some support for the Supreme Court's assertion in Wheat that defense lawyers with conflicts of interest may be inclined to seek waivers from their clients. See supra note 65; see also Gross, supra note 23 (whose study comes to the same conclusion).

175. Disclosure might be effective in situations where the risks of conflict are low, the disclosure is appropriate, and the capacity of the decision-maker to make informed judgments is strong. See Cain, Coming Clean but Playing Dirtier, supra note 164, at 117. 


\section{B. Trial Court Discretion}

The decision in Wheat to grant trial courts wide discretion to disqualify counsel when conflicts of interest are alleged has drawn criticism. ${ }^{176}$ Much of the concern raised is that too much discretion undermines the defendant's autonomy in choosing counsel and also has associated costs, including interference with confidential communications between counsel and the defendant, undermining the defendant's faith in counsel, and chilling advocacy on behalf of the defendant. ${ }^{177}$ In addition, courts may not have access to the necessary information to decide whether a conflict exists or is likely, especially if the basis for the purported conflict comes from information provided to defense counsel through confidential communications. ${ }^{178}$

These criticisms may be well-founded. However, the present purpose is not to decide whether courts are better suited than defense attorneys to address and resolve conflicts, but rather to determine whether empirical evidence supports assertions that have been made about how defense attorneys respond to conflicting interests. On that question, at least, the empirical data does not provide a basis to disturb the Supreme Court's conclusion granting trial courts discretion in this area. ${ }^{179}$

\section{Prohibit Multiple Representation}

Some have argued that the only viable way to ensure that conflicts of interest do not damage defendants, at least in cases of multiple

176. See, e.g., Green, supra note 22 (criticizing Wheat); see also Alfredo Garcia, The Right to Counsel Under Siege: Requiem for an Endangered Right?, 29 AM. CRIM. L. REV. 35, 97 (1991) (criticizing Wheat).

177. See Green, supra note 22, at 1232 .

178. Id. at $1230-32$ (explaining that much of the information necessary to determine whether a conflict is present may be based on confidential communications).

179. Research indicates that distancing the person with conflicting duties from the decision on whether a conflict exists is the best way to reduce the impact of the conflict, meaning that -all other things being equal - a neutral arbiter is in the best position to calculate whether a conflict exists or is likely. See Chugh et al., supra note 25, at 91; see also Gross, supra note 23, at 145 (suggesting shifting the decision-making authority away from the lawyer who is subject to a conflict of interest); Moore et al., Moral Seduction, supra note 120, at 24 (suggesting solutions to the problems of auditor independence, including removing the decision-making responsibility from the person or entity with the conflict of interest). In theory, trial courts should be able to perform this function well. Practice, however, may be very different. For example, a trial court may be inclined to disqualify counsel, even when the risks of divided loyalties are relatively low, as a preventive measure to preserve a judgment from attack on appeal. See Green, supra note 22, at 1240-41 (discussing the institutional interests of the judiciary to preserve judgments). 
representation, is a flat prohibition. ${ }^{180}$ The disadvantage to this solution, of course, is that it denies defendants the right to counsel of choice in situations where multiple representation would be beneficial. As Justice Frankfurter noted more than sixty years ago in an oft-repeated passage, "[j]oint representation is a means of insuring against reciprocal recrimination. A common defense often gives strength against a common attack." 181 While these benefits may be outweighed by the risks caused by multiple representation, prohibition should be a last resort, to be used only when no other alternatives are available. Fortunately, a better choice exists.

\section{Replace the Sullivan "Adverse Effects" Test}

The research on psychology of conflicts of interest indicates that many lawyers will underestimate the corrosive effects of a conflict and then, when asked to provide an explanation about the decisions made on behalf of the defendant, will provide post hoc rationalizations that are inconsistent with what really transpired. ${ }^{182}$ Combined with other problems of proof, these systemic biases in judgment raise questions about the propriety of the Sullivan adverse effects test in conflicts cases. A better approach would be to focus on the risk that there was a conflict of interest in the first place, and not on whether the defendant can prove that a conflict produced an adverse effect.

Proving that a conflict of interest caused a specific result is difficult even when psychological biases are not factored into the equation. As previously noted, conflicts often cause a lawyer to refrain from acting in

180. See, e.g., Debra Lyn Basset, Three's a Crowd: A Proposal to Abolish Joint Representation, 32 RUTGERS L. J. 387, 393 (2001) (arguing for a per se rule prohibiting joint representation because the dangers far outweigh potential benefits); Geer, supra note 30, at 157-62 (proposing that the ABA Code of Professional Responsibility be interpreted to prohibit attorneys from representing multiple defendants in the same case); Peter W. Tague, Multiple Representation and Conflicts of Interest in Criminal Cases, 67 GEO. L. J. 1075, 1075-76 (1979) (discussing the benefits of individual representation and various ways to bring about those benefits).

181. Glasser v. United States, 315 U.S. 60, 92 (1942) (Frankfurter, J., dissenting), overruled in part by Bourjaily v. United States, 483 U.S. 171 (1987). Others have described these benefits. See, e.g., Ephraim Margolin \& Sandra Coliver, Pretrial Disqualification of Criminal Defense Counsel, 20 AM. CRIM. L. REV. 227, 251-57 (1982) (discussing the practical and constitutional arguments in favor of joint representation). For an interesting debate about the merits of multiple representation, see FREEDMAN \& SMITH, supra note $61, \S 11.17$ n.190 (discussing a disagreement between the coauthors, both eminent scholars, about the propriety of multiple representation in criminal casesFreedman believes that multiple representation can sometimes be beneficial to all concerned, whereas Smith believes that a single lawyer should never represent multiple defendants in the same case).

182. See supra notes $109-43$ and accompanying text. 
a manner that would otherwise benefit the defendant, ${ }^{183}$ yet proving the harm caused by such "absence of footprints" is difficult. ${ }^{184}$ For example, in a case of multiple representation, a defendant might allege that a conflict of interest discouraged the defense lawyer from seeking a favorable plea bargain out of loyalty to other defendants. In such a situation, the defendant would need to prove that defense counsel should have been more aggressive in seeking a favorable plea bargain and that the failure to do so was caused by conflicting duties. ${ }^{185}$ Evidence to support these claims might be obvious - for example, if the defense attorney failed to engage in any plea negotiations on behalf of the defendant when under the circumstances any competent defense attorney would have done so. But what about a case where the alleged failure is more subtle? It is much harder to prove that a defense attorney, who did negotiate on behalf of the defendant, did not do so aggressively enough, or that an attorney who did investigate and sought exculpatory evidence did not do so vigorously enough. Recreating what would have, or should have, occurred had the defendant received conflict-free representation is not easy, even assuming that the evidence to prove these claims is readily available. $^{186}$

183. Holloway v. Arkansas, 435 U.S. 475, 489-90 (1978).

184. See id. at 491; see also Cuyler v. Sullivan, 446 U.S. 335, 356-57 (1980) (Marshall, J., concurring in part and dissenting in part) (noting the difficulty in proving an adverse effect from "what the advocate finds himself compelled to refrain from doing"" (quoting Holloway, 435 U.S. at 490-91)); Green, supra note 22, at 1207 n.29.

185. See, e.g., United States v. Moss, 323 F.3d 445, 468 (6th Cir. 2003) (“[I]n order to prevail on a claim of ineffective assistance, a petitioner alleging that a conflict of interest prevented his attorney from exploring plea negotiations must demonstrate (1) there was a conflict of interest; and (2) that the conflict of interest prevented the attorney from exploring plea negotiations."); Ruffin v. Kemp, 767 F.2d 748, 751-52 (11th Cir. 1985) (per curiam) (finding reversible error where counsel who represented co-defendants failed to negotiate a plea bargain on behalf of one defendant because of duties owed to another defendant). In addition, some courts require proof that the prosecution would have been willing to offer a better deal than defense counsel obtained. See, e.g., Goldsby v. United States, 152 F. App'x 431, 437 (6th Cir. 2005); Moss, 323 F.3d at 468; Jones v. Sec'y, Dep't of Corr., No. 8:04-cv-1930-T-24MSS, 2008 WL 906653, at*20 (M.D. Fla. Mar. 31, 2008). But see United States v. Williams, 372 F.3d 96, 107 (2d Cir. 2004) (holding that defendant need not prove that the government would have offered a plea deal, when there is sufficient evidence that defense counsel who had an actual conflict of interest did not make any significant efforts to negotiate a plea bargain on the defendant's behalf).

186. The difficulty of proof has caused others to criticize the adverse effects test, including Justice Marshall, who stated in Sullivan that a test requiring a defendant "to demonstrate that his attorney's trial performance differed from what it would have been if the defendant had been the attorney's only client ... is not only unduly harsh, but incurably speculative as well." Sullivan, 446 U.S. at 355 (Marshall, J., concurring in part and dissenting in part). Gary Lowenthal provides another example, one that could occur in the case of successive representation where the defense attorney previously represented a prosecution witness. Lowenthal, supra note 33, at 33-34. Say, for example, the defense attorney thoroughly cross-examined the prosecution's witness and avoided only one area of examination - the area that concerned confidential information gleaned from the prior representation of the prosecution witness. Id. In such circumstances, even if the transcript 
These problems of proof are substantially worse when the psychological biases of the defense attorney are considered. For example, in the case of multiple representation just described, if the defense attorney in good faith believes that additional plea negotiations would have been fruitless, and testifies to that effect at the postconviction hearings, disproving that claim will be almost impossible. To be sure, the defendant might be able to get the defense attorney to admit that more investigation could have been conducted, and might even be able to demonstrate that uncovering additional facts could have been helpful in plea negotiations, but that would be insufficient. The defendant will still need to prove that the conflict of interest caused the attorney's inaction. ${ }^{187}$ The attorney whose conduct is under review can be expected to resist this conclusion because of an inability to perceive the unconscious biases that influence judgment. Introspection into automatic bias is just not possible. ${ }^{188}$ Because the defense attorney's testimony will be the most probative evidence available, the psychological biases that discount conflicts of interest will make it much harder for the defendant to prove that the conflict caused an adverse effect on representation provided.

Mickens again provides a good illustration of these problems. Justice Kennedy emphasized in his opinion that Bryan Saunders believed that he had no continuing duty of confidentiality to the victim and that, as a result, Mickens could not prove that any of the alleged errors in representation resulted from a conflict of interest. ${ }^{189}$ One can never know for certain whether psychological biases caused Saunders to miscalculate the influence of his prior representation on decisions made while representing Mickens. Saunders might have been one of those rare

suggests a "lengthy and vigorous" cross-examination, the decision to avoid only one subject may still deny the defendant a "fair opportunity for acquittal. Yet proving that a conflict of interest caused the lawyer's conduct will be difficult, especially since there may have been other tactical reasons unrelated to the conflict that can explain the lawyer's decisions." Id.

187. See cases cited supra notes 84-85 and accompanying text.

188. Indeed, the research reveals that people are unable to control subconscious biases even when they are aware of them. Lauren E. Willis, Against Financial-Literacy Education, 94 IowA L. REV. 197, 249 (2008) (citing Asher Koriat et al., Reasons for Confidence, 6 J. EXPERIMENTAL Psychol.: Hum. LeARning \& MEMORY 107, 114, 117 (1980)); Timothy D. Wilson et al., Mental Contamination and the Debiasing Problem, in Heuristics AND Biases: The Psychology OF INTUITIVE JUDGMENT 125-26 (Thomas Gilovich et al. eds., 2002)). This is not to say that attorneys can never identify or testify accurately about conflicts of interest. As the Sullivan remand demonstrates, when a conflict is obvious, an attorney can and will be able to explain that the conflict had an adverse effect on the decisions made during trial. See cases cited supra notes 92-95 and accompanying text. It is in the closer cases, when the impact of a conflict is not so apparent, where the defense attorney will be more likely to provide post hoc rationalizations that understate the likelihood of a conflict or its corrosive effects.

189. Mickens v. Taylor, 535 U.S. 162, 177-79 (Kennedy, J., concurring). 
people who, through the sheer power of moral reasoning, was able to overcome his unconscious biases. ${ }^{190}$ Given his ethical limitations, ${ }^{191}$ however, it is more likely that he provided a post hoc rationalization to justify his own behavior. If so, he would have underestimated both the likelihood of conflict at the time he decided to accept representation of Mickens and also when testifying about these matters after conviction. Mickens was placed in the untenable position of trying to undermine unconscious biases, a burden he could not meet.

Given these proof problems, it is not surprising that there are only a small number of reported decisions in which defendants are able to meet the Sullivan adverse effects test. ${ }^{192}$ One explanation is that conflicts rarely infect criminal proceedings. But the research on psychological biases provides an alternative and more likely explanation: the Sullivan adverse effects test erects too high a barrier in conflicts cases, meaning that many conflicts are never identified because of problems of proof, not because they do not exist.

A better approach, which will help reduce the effect of psychological biases in criminal cases, is to focus on the degree of risk that a conflict existed. This alternative test, which would be named the "substantial risk" test, borrows from modern ethical rules that focus on risk, not

190. The Emotional Dog, supra note 128, at 819 (discussing instances where rational deliberation can overcome unconscious bias).

191. See case cited supra note 13 and accompanying text.

192. Calculating the success rate of claims based on conflicts of interest is difficult, as there is no central source that collects data from the myriad of federal and state courts where prosecutions take place and then synthesizes it according to type of claim asserted. But there should be little dispute that few claims alleging ineffectiveness due to a conflict of interest are successful. The most exhaustive data set available on successful ineffectiveness claims is compiled by the Capital Defender Network, a program of the Office of Defender Services of the Administrative Office of the United States Courts. According to the Network's report on all published opinions of successful ineffectiveness claims (from 1982 to 2004), there have been only a few hundred successful claims in both state and federal courts where the defendant alleged a conflict of interest. See TERESA L. Norris, Summaries of All Published SuCCESSFul CONFlict OF INTEREST Claims SinCE 1982 (2004), http://www.capdefnet.org/hat/contents/constitutional_issues/conflict/conflict_frame.htm (last visited Aug. 25, 2009). In contrast, during the same period there were an excess of 300,000 petitions for habeas corpus seeking relief from state and federal convictions filed in the United States District Courts. Albany.edu, Sourcebook of Criminal Justice Statistics, Table 5.65, http://www.albany.edu /sourcebook/pdf/t5652007.pdf (last visited Aug. 26, 2009). Ineffective assistance of counsel is the most frequently raised basis for habeas relief. ROGER A. HANSON \& HENRY W. K. DALEY, BUREAU of Just. Stat., Federal Habeas Corpus Review: Challenging State Court Criminal CONVICTIONS v (1995), available at http://www.ojp.usdoj.gov/bjs/pub/pdf/fhcrcscc.pdf. Even if only a fraction of the habeas claims filed alleged a conflict of interest as a basis for relief, the ratio of successful claims to claims made would still be extremely small. The ratio would be even smaller if the number of claims alleging a conflict of interest in state courts was factored into the equation; unfortunately, no such source of data is available. 
result. ${ }^{193}$ It also seeks to enforce the duty of inquiry imposed when a trial court knows or should know that a conflict is present. ${ }^{194}$

Under the substantial risk test, a defendant who is seeking a new trial based on a conflict of interest would be required to meet the same standard of proof as set forth in the Restatement of the Law Governing Lawyers, meaning that the defendant must establish that, based on the information that was known to defense counsel at the time, there was "a substantial risk that the lawyer's representation" of the defendant "would be materially and adversely affected by the lawyer's own interests or by the lawyer's duties to another current client, a former client, or a third person." $" 195$ If the defendant can prove that such risk existed, then a conflict has been established and the defendant's conviction should be reversed without requiring the defendant to prove also that the conflict had an adverse effect on the representation provided. ${ }^{196}$

Focusing on the degree of risk before conviction will help alleviate some of the problems of proof in conflicts cases. Post-conviction proceedings will still be necessary in most cases, but the focus will be on proving the risk of conflict, rather than whether the conflict had an impact on decisions made during representation. For example, in a case of multiple representation, a defendant could demonstrate a conflict by proving that the defendants had antagonistic defenses that could not be advocated simultaneously, which by itself would raise sufficient risk of conflict. The defendant would no longer also need to prove that the antagonistic defenses resulted in any adverse effect in decisions made during the representation.

In addition, the substantial risk test will make the testimony of defense counsel less important. For example, on the issue of consent in Mickens, the focus would have been on what a competent attorney would have done, given the information known at the time, to investigate the

\footnotetext{
193. See supra notes $42-46$ and accompanying text.

194. For a discussion of the duty of inquiry, see supra note 76 and accompanying text.

195. See supra note 46 and accompanying text.

196. The amicus brief filed by experts in legal ethics in Mickens proposed a similar test. Brief of Legal Ethicists, supra note 21, at *9 (arguing for an "objective test," which asks "did the lawyer have other interests that posed a substantial risk of materially and adversely affecting the representation?"). Similarly, Gary Lowenthal has suggested a variation on this test, but limited only to situations of successive representation. Lowenthal, supra note 33, at 36. In his view, defense attorneys should be required to report any prior representation of a prosecution witness to the trial judge. Id. If the defense attorney fails to do so, then the defendant should be permitted to obtain relief from the conviction by showing that the prior representation of the witness was substantially related to the representation of the defendant, irrespective of whether the prior representation of the witness caused any harm to the defendant. Id. My proposal expands this test to all cases where the defendant can prove there was sufficient risk of a conflict, as defined by the Restatement.
} 
defense. What evidence was there to suggest a consent defense? Were there reasonable investigative leads that could have been pursued to help prove the defense? Would a competent lawyer in Saunders's position have been expected to use information gained during the representation of the victim in such an investigation, yet been constrained to do so because of the prior representation of the victim? Proving that a nonconflicted lawyer would have investigated the consent defense would go a long way to meet this burden. ${ }^{197}$ Mickens would not have been obligated to go further, as required by Sullivan, to prove that the reason that Saunders failed to pursue the consent defense was because he had previously represented the victim-thus eliminating the need for Saunders's subjective assessment of his own reasons for his own conduct. Rather, the inquiry would be an objective assessment of the risks that existed prior to conviction.

Of course, substituting the degree of risk for the adverse effects test will not eliminate the need for testimony from defense attorneys. Rather, to prove the degree of risk, the defendant will often need to call the attorney whose conduct is under review. But the questions posed to the defense attorney would likely focus more on the historical facts of representation, and less on explanations for why certain decisions were made. For example, if the question before the reviewing court is whether multiple representation caused a defense attorney to forgo a favorable plea bargain, the defense attorney might need to testify about whether plea negotiations took place and whether the prosecutor made any favorable offers, but would not need to explain whether the circumstances that led to the alleged conflict caused the defense attorney's conduct. In all likelihood, if the defense attorney represented multiple clients with differing defenses, and failed to engage in meaningful plea negotiations on behalf of the defendant when such negotiations would have been expected, then the risk would be sufficient to warrant relief, irrespective of the explanations that the defense attorney proffered. By eliminating a focus on the defense attorney's own assessment of his or her conduct, the substantial risk test will reduce the influence of unconscious biases that have been identified in this Article.

197. There is certainly reason to believe that Saunders failed to investigate a consent defense because of his prior representation of the victim. As previously noted, much of the evidence concerning a possible consent defense turned on whether the victim was a male prostitute. See case cited supra note 8 and accompanying text. To investigate this claim, a non-conflicted lawyer would have been expected to pursue all reasonable leads, including investigating and revealing the victim's criminal record. Mickens v. Greene, 74 F. Supp. 2d 586, 610 (E.D. Va. 1999). However, Saunders could not pursue such an investigation without revealing that he had represented the victim on criminal charges, information that he seemed determined to keep secret. See id. at 599-601. 
A number of questions are raised by this proposal. The first is whether a defendant should receive a new trial if it can be established that the risk of a conflict before conviction was sufficiently great to meet the substantial risk test, but the trial court did not have reason to know of the circumstances that led to that risk. For example, in a case of successive representation where the defense attorney had previously represented either the victim or one of the prosecution's witnesses, the defense attorney may have failed to disclose any information about the prior representation to either the defendant or the trial court. If the defendant learns of the prior representation after conviction, and brings a collateral challenge based on that claim, should the defendant receive a new trial?

The argument against granting a new trial, at least in the absence of proof of an adverse effect, is that the trial court did not know, nor had reason to know, that a conflict might be present and therefore could not have prevented it. The opposite argument is that the defendant deserves loyalty from defense counsel, and the trial court's knowledge should be irrelevant in making that decision. Between these two options, the latter view is better: the purpose of the Sixth Amendment is to protect the defendant's right to a fair trial in all cases, even when no blame can be cast on the trial court. If the defendant can establish that a conflict existed, it should not matter that the trial court was not in a position to prevent it.

Second, some will argue that the substantial risk test will allow defendants to obtain new trials too frequently, thus undermining finality of judgments in too many cases. ${ }^{198}$ This will only be a problem if defendants receive new trials in cases where a conflict of interest had no measurable influence on decisions made during representation. There are reasons to be cautiously optimistic that such cases will be few: to begin with, because psychological biases are systematic, their corrosive effects on judgment and decision-making will occur in most cases. ${ }^{199}$ At the very least, whenever circumstances create a substantial risk of a material and adverse limitation in representation, there will be a similar risk that the lawyer's judgment will be influenced in some significant respect. The danger of opening a floodgate of unwarranted reversals, therefore, will be minimal. In addition, the proposed test will create an incentive for trial courts to ferret out conflicts of interest whenever

198. See generally Paul M. Bator, Finality in Criminal Law and Federal Habeas Corpus for State Prisoners, 76 HARV. L. REV. 441 (1963) (discussing the importance of finality in criminal cases).

199. See supra notes 110-19 and accompanying text. 
possible. Knowing that a verdict would be susceptible to reversal when there is sufficient risk of a conflict, trial courts will have an incentive to identify and resolve conflicts before conviction. ${ }^{200}$ The proposed test may act as a prophylactic, resulting in fewer rather than more cases in which convictions need to be reversed. As a result, the proposed test is not likely to produce a windfall for undeserving defendants; rather, it is more likely to result in a more accurate way of determining how conflicts do, in fact, influence decision-making in criminal cases.

Finally, because the new test might cause trial courts to err on the side of finding conflicts in ambiguous cases as a way to preserve judgments from attack, there will be some instances where a defendant's right to choose his or her own counsel will be compromised. Trial courts can minimize this danger by making sure that any circumstances that can give rise to a conflict are addressed as early as possible in a proceeding to minimize the damage caused by a disqualification motion. In addition, courts must take care not to allow disqualification motions to be used as a gambit to undermine the defendant's choice of counsel. ${ }^{201}$ However, even with these precautions, there may be cases where an alleged conflict results in unfair disqualification of counsel. If so, the result will only be replacement of counsel by a new attorney who is conflict-free. This price is worth it for a system that returns better results in determining when conflicts of interest are present. ${ }^{202}$

In sum, the substantial risk test should help reviewing courts make better assessments about whether a lawyer had a conflict of interest. While it will not eliminate the problems of proof that have been identified, it will help reduce the psychological biases that make it difficult for a defendant to prove violations of the Sixth Amendment right to effective assistance of counsel. The net result should be more accurate assessments of how conflicts do, in fact, influence decisionmaking in criminal cases.

200. This is the same incentive created by Holloway v. Arkansas, which encourages the avoidance of conflicts of interest before they arise. See Lowenthal, supra note 33, at 41-42.

201. Appellate courts will, of course, need to continue to monitor disqualification decisions to make sure that trial courts do not abuse their discretion in granting disqualification motions. See, e.g., Hanna v. State, 714 N.E.2d 1162, 1165 (Ind. Ct. App. 1999) (finding that trial court erred in disqualifying counsel where the prosecution objected to joint representation); Ex parte Tegner, 682 So.2d 396, 398 (Ala. 1996) (finding that trial court erred in disqualifying defense counsel in murder case without sufficient inquiry to determine whether counsel's previous representation of an eyewitness constituted a conflict of interest).

202. This is not to say that there will be no cost to requiring replacement counsel. See Lowenthal, supra note 33, at $25 \mathrm{n} .85$ (discussing some of the costs that a client might incur, including the additional expense of hiring new counsel and the additional work that new counsel will need to do to become familiar with the client's case). 


\section{CONCLUSION}

Conflicts of interest exert subtle psychological influence on judgment and decision-making. Empirical research demonstrates that lawyers, like all professionals, are subject to psychological biases that make it difficult to be objective when balancing self-interest with duties to others. The results are systematic errors of judgment that favor selfinterest.

Applying psychological research to criminal cases reveals that many of the claims about how defense lawyers allegedly respond to conflicts of interest are incorrect. Contrary to assumptions that have been made, defense lawyers are not well-suited to evaluate conflicts that can and do arise during criminal proceedings. Similarly, they tend to be poor judges of whether a conflict of interest had a corrosive effect on decisions made during representation.

Given the evidence, current doctrine should be re-evaluated to better align existing legal rules with how lawyers actually behave when conflicts are present or likely. The Supreme Court's conclusion in Wheat, which granted trial courts substantial latitude in making disqualification decisions, is consistent with the results of the psychological research. While there may be other valid reasons to critique the degree of discretion courts possess to disqualify lawyers, the available empirical evidence is not one of them. In contrast, given the inability of defense lawyers to make accurate assessments about their own behavior, the Sullivan adverse effects test for determining whether a defendant received effective assistance of counsel erects too high a barrier of proof. A better test would emphasize the degree of risk that existed before conviction. Under the proposed substantial risk test, a new trial would be required if a defendant can prove, based on the facts known before conviction, that there was a substantial risk that the defense lawyer's representation "would be materially and adversely affected by the lawyer's own interests or by the lawyer's duties to another current client, a former client, or a third person." 